\title{
Predictions of the mutual events of the Uranian satellites occurring in 2006-2009
}

\author{
J.-E. Arlot ${ }^{1}$, V. Lainey ${ }^{2,1}$, and W. Thuillot ${ }^{1}$ \\ 1 Institut de mécanique céleste et de calcul des éphémérides - Observatoire de Paris, UMR 8028 CNRS, 77 avenue Denfert-Rochereau, \\ 75014 Paris, France \\ e-mail: Jean-Eudes.Arlot@imcce.fr \\ 2 Observatoire Royal de Belgique, Avenue Circulaire 3, 1180, Bruxelles, Belgium
}

Received 7 March 2006 / Accepted 28 April 2006

\begin{abstract}
Context. Every 42 years, the Earth and the Sun pass through the equatorial plane of Uranus allowing observations of mutual occultations and eclipses of the main satellites of Uranus. The next opportunity will occur in 2006-2009.

Aims. Such events are uncommon and very rare, and they allow us to accurately determine the inclinations of the orbits of the satellites, which is usually difficult. However, in order to be able to observe, we need accurate predictions.

Methods. To find these predictions, we developed a new dynamical model based on the most recent astrometric observations of the satellites.

Results. This paper provides predictions of these events using two different models for the motion of the satellites, along with information useful for the observations. Data on the predictions of the events are available on the web server of the IMCCE at ftp.imcce.fr/pub/ephem/satel/pheura07.

Conclusions. We therefore encourage professional and amateur astronomers to join the network of observers to get as many observations as possible.
\end{abstract}

Key words. planets and satellites: general - eclipses - occultations - ephemerides

\section{Introduction}

The best-known mutual events are those of the Galilean satellites, which occur every six years and which have been extensively observed since 1973 . Such observation campaigns show how to observe and how to use the data that provide astrometric relative positions of the satellites with high accuracy. Improvements in detectors have made it possible to observe the events of the main satellites of Uranus, which are fainter that the Galilean ones. The orbits of the Uranian satellites have little known inclinations due to a geocentric polar view of the system from Earth most of the time, and they may be accurately determined through observations of the mutual events.

To predict these events, we used the early model of Laskar \& Jacobson (1987, GUST86) and a new one based on more recent observations named LA06 described below.

\section{The mutual events}

Since the Uranian satellites have their orbits almost in the same plane, mutual events occur regularly when the Earth (for the occultations) and the Sun (for the eclipses) pass through the common orbital plane of the satellites. This plane corresponds closely to the equatorial plane of Uranus. This occurrence takes place at the "equinox" on Uranus, i.e. when the uranocentric declination of the Sun (and the Earth, which appears to be very close to the Sun as seen from Uranus) are near zero. Table 1 shows

* Tables 7-28 are only available in electronic form at http://www.edpsciences.org the variation of these uranocentric declinations in Cols. (2) and (3): the best period for large, deep, mutual events appear to be May 2007 to February 2008. Fortunately, the opposition of Uranus with the Sun occurs in the middle of the period, allowing observations during almost all the period. Note that the declination of Uranus will be between -4 and -8 degrees allowing observations as well in the northern hemisphere as in the southern. The opposition will occur in September when days and nights have the same length everywhere on Earth.

The description of the mutual eclipses and occultations have been made in previous papers, especially in technical notes available on the web site of the IMCCE at the address http: //www . imcce. fr/pheura07 or in Arlot (1999).

The occultations consist in the arrival of the disk of the occulting satellite on the one of the occulted satellite. Therefore, the amount of light received by an Earth-based observer decreases and then increases during the event. The eclipses correspond to the arrival of the eclipsed satellite in the shadow cone of the eclipsing satellite. In that case, only the eclipsed satellite may be observed, leading, in some cases, to a total eclipse (the complete disappearance of the eclipsed satellite). During the occurrence of the mutual events, the magnitude of the events will be small at the beginning and the end of the period (the uranocentric declinations of the Earth and the Sun is not yet zero, and the satellites are not exactly on the same line as seen from the Earth (or the Sun). In contrast, the magnitude of the events will be greater for the zero value of the uranocentric declination of the Earth and the Sun. Observers should be aware that the signal-to-noise ratio will be larger for deep phenomena. 
Table 1. Observability of the mutual events.

\begin{tabular}{|c|c|c|c|c|c|c|c|}
\hline Year & (1) & (2) & (3) & (4) & (5) & (6) & (7) \\
\hline \multirow[t]{8}{*}{2006} & May & -4. & -6. & 1 & - & 70 & -7 . \\
\hline & June & -3 . & -5.5 & 3 & - & 100 & -6.5 \\
\hline & July & -3 . & -5.5 & 2 & - & 130 & -7 \\
\hline & August & -3.5 & -5 & - & - & 160 & -7 \\
\hline & September & -4 & -4.5 & - & - & 173 & -7.5 \\
\hline & October & -6 & -4.5 & - & - & 142 & -8. \\
\hline & November & -6.5 & -4 & - & - & 112 & -8.5 \\
\hline & December & -7 & -4. & - & - & 82 & -8. \\
\hline \multirow[t]{12}{*}{2007} & January & -6 & -3.5 & - & - & 52 & -8 . \\
\hline & February & -5 & -3 & - & - & 23 & -7 . \\
\hline & March & -3.5 & -3 & 5 & - & 5 & -7 . \\
\hline & April & -1.5 & -2.5 & 9 & 5 & 34 & -6 . \\
\hline & May & -0.5 & -2.5 & 12 & 5 & 61 & -5.5 \\
\hline & June & 0.5 & -2 & 2 & 7 & 90 & -5.5 \\
\hline & July & 1 & -2 . & 2 & 9 & 120 & -5 \\
\hline & August & -0.5 & -1.5 & 16 & 5 & 150 & -5.5 \\
\hline & September & -1 & -1 & 6 & 4 & 183 & -6 \\
\hline & October & -2 & -1 & 3 & 10 & 152 & -6.5 \\
\hline & November & -2.5 & -0.5 & - & 11 & 122 & -7 . \\
\hline & December & -3 & 0. & - & 34 & 85 & -7 \\
\hline \multirow[t]{12}{*}{2008} & January & -2 & 0. & 9 & 2 & 52 & -6.5 \\
\hline & February & 0. & 0.5 & 18 & 3 & 23 & -6 \\
\hline & March & 1. & 1. & 1 & - & 6 & -5 \\
\hline & April & 3. & 1. & - & 1 & 34 & -4.5 \\
\hline & May & 4. & 1.5 & - & 1 & 34 & -4.5 \\
\hline & June & 5. & 2. & - & - & 90 & -4 \\
\hline & July & 5. & 2. & - & 1 & 119 & -4 \\
\hline & August & 4. & 2.5 & 1 & 2 & 14 & -4 \\
\hline & September & 3. & 3. & - & - & 118 & -4 \\
\hline & October & 2. & 3. & 1 & - & 152 & -5 . \\
\hline & November & 1.5 & 3.5 & - & - & 121 & -5 . \\
\hline & December & 1. & 4. & 2 & - & 90 & -5 . \\
\hline
\end{tabular}

(1): Month; (2): Uranocentric declination of the Earth to the nearest half-degree; (3): Uranocentric declination of the Sun to the nearest half-degree; (4): Number of occurring occultations; (5): Number of occurring eclipses; (6): Angular distance Sun-Uranus (elongation to the nearest degree); (7): Declination of Uranus in degrees (to the nearest half-degree).

\section{The eclipses and events by the planet Uranus}

As it occurs regularly with the Galilean satellites, the satellites of Uranus will present occultations by the disk of Uranus, eclipses by its shadow, transits of the satellites on the disk of the planet and transits of the shadows of the satellites on this disk. Note that only eclipses and maybe the transits of the shadows of the satellites on the disk of the planet are easily observable. Eclipses may be interesting for infrared observations of the eclipsed satellites and we will publish the dates soon (Thuillot et al. 2006). For our purpose, we used the dates of these events for the elimination of the mutual events that are not observable due to the presence of the planet Uranus.

\section{The predictions for $2006-2009$}

Before predicting the events, we have to find or build accurate ephemerides, then use an algorithm such as the previous one used for the former predictions of mutual events.

\subsection{The dynamical models used for the calculations}

Predicting these events requires the use of an accurate orbital model of the Uranian satellites, especially for the inclinations of the satellites, because the mutual events are very sensitive to the relative latitudes of the satellites on the equator of Uranus. The difference of a few hundredths of an arcsecond in the relative positions of the Uranian satellites may affect whether the event will occur or not. Unfortunately, the models of motions are built using observations mostly performed when the Uranian system was seen from its pole, leading to incorrect determination of the orbit inclinations. Therefore, we used two different ephemerides based upon two different sets of observations and two different dynamical models. The first one is from the Laskar-Jacobson theory (Laskar 1986; Laskar \& Jacobson 1987) based on observations from 1911 to 1986 (referenced by GUST86 below).

The second model is a preliminary version of new ephemerides for the Uranian system that are described in Lainey $\&$ Arlot (2006). These preliminary ephemerides were developed by means of NOE (Numerical Orbit and Ephemerides) software to model the orbital motion of the satellites. This code was developed at the Royal Observatory of Belgium mainly for the purpose of natural-satellite ephemerides and applied successfully to the Martian moons (Lainey et al. 2006). It is an $\mathrm{N}$-body code that incorporates highly sensitive modeling and that can generate partial derivatives. The latter ones are needed to fit the initial positions, velocities, and other parameters (masses, $J_{2}, J_{4}, \ldots$ ) to the observational data. The numerical procedure used is actually very similar to the one presented in Taylor (1998). This new model introduces the Uranian gravity field by means of $C_{20}$ and $C_{40}$ coefficients borrowed from (French et al. 1988) and the solar perturbation using DE406 ephemerides (Standish 1998). The masses of the Uranian system were taken from (Jacobson et al. 1992) and the Uranian precession from IAU 2000 (Seidelmann et al. 2002). A large set of 11359 observations (Miranda: 1922; Ariel: 2227; Umbriel: 2230; Titania: 2483; Oberon: 2497) covering the period 1948-2003 was used (cf. Tables 2-4). During the fit procedure, only the initial position and velocity components of each satellite were adjusted in this preliminary version. Weights were introduced using a former estimation of each observationally set accuracy. Intersatellite positions were considered. Tables $2-4$ present the post-fit residuals of all the observations used. Note that some sets of data include too few observations to provide confident statistical data.

We present the predictions using the ephemerides from both GUST86 and LA06. Are they confident enough that they will find the mutual events? We know that the precision (internal error) of GUST86 is from 10 to $100 \mathrm{~km}$ for a ten-year period. The precision of LA06 is around $10 \mathrm{~m}$. The accuracy (external error) of GUST86 is shown by recent observations (Stone \& Harris 2000) to be around 0.1 arcsec. The accuracy of LA06 has been around 0.05 arcsec (cf. Table 2) for recent observations. Events should be more accurately predicted using LA06, but the observations of the mutual events will be able to confirm the predictions or not.

\subsection{The predictions of the events}

The calculations for the prediction of the events differ for the occultations and for the eclipses. For the occultations, we determinate the time of the first contact, maximum, and last contact of the two disks of the satellites as seen from the Earth. For the eclipses, we do not consider that they are occultations as seen from the Sun because of the light-time, but that they are occultations of the Sun as seen from the eclipsed satellites. Therefore, we calculate the first and last contacts of the eclipsed satellite with the penumbral and umbral cones and the time of the minimum distance to the axis of the cones. The relative positions 
Table 2. Values of the mean $v$ and standard deviations $\sigma$ on right ascension and declination in arcsecond for each satellite residuals, $N$ being the number of observations used by satellite $(1 / 2)$.

\begin{tabular}{lcccccl}
\hline \hline Observations & $v_{\alpha}$ & $\sigma_{\alpha}$ & $v_{\delta}$ & $\sigma_{\delta}$ & $N$ & Satellite \\
\hline 1983-1998 & 0.0040 & 0.0668 & 0.0095 & 0.1084 & 1536 & Ariel \\
Veiga et al. (2003) & 0.0005 & 0.0665 & 0.0136 & 0.1081 & 1526 & Umbriel \\
& 0.0017 & 0.0680 & 0.0145 & 0.1086 & 1541 & Titania \\
& 0.0049 & 0.0745 & 0.0048 & 0.1113 & 1541 & Oberon \\
& -0.0130 & 0.2317 & -0.0493 & 0.4350 & 1320 & Miranda \\
\hline 1987-1994 & 0.0137 & 0.3018 & -0.0187 & 0.3339 & 106 & Titania \\
Chanturiya et al. (2002) & 0.0439 & 0.3270 & 0.0116 & 0.3220 & 103 & Oberon \\
\hline 1998-2000 & -0.0012 & 0.0994 & 0.0013 & 0.0859 & 156 & Titania \\
Stone (2001) & -0.0304 & 0.1209 & -0.0014 & 0.0870 & 175 & Oberon \\
\hline 1999 & -0.0100 & 0.0150 & 0.3376 & 0.1454 & 3 & Ariel \\
Owen (1999) & -0.0103 & 0.0229 & -0.2032 & 0.1025 & 3 & Umbriel \\
& 0.0926 & 0.0731 & -0.0707 & 0.0122 & 3 & Titania \\
& -0.0723 & 0.0590 & -0.0638 & 0.0386 & 3 & Oberon \\
\hline 2001 & -0.0534 & 0.0320 & 0.2146 & 0.0213 & 3 & Umbriel \\
Owen (2001) & 0.0209 & 0.0154 & -0.1504 & 0.0189 & 3 & Titania \\
& 0.0325 & 0.0229 & -0.0642 & 0.0085 & 3 & Oberon \\
\hline 2003 & -0.0166 & 0.0332 & 0.0520 & 0.0152 & 6 & Titania \\
McNaught et al. (2003) & 0.0166 & 0.0332 & -0.0520 & 0.0152 & 6 & Oberon \\
\hline
\end{tabular}

Table 3. Values of the mean $v$ and standard deviations $\sigma$ on right ascension and declination in arcsecond for each satellite residuals, $N$ being the number of observations used by satellite $(2 / 2)$.

\begin{tabular}{lccccrl}
\hline \hline Observations & $v_{\alpha}$ & $\sigma_{\alpha}$ & $v_{\delta}$ & $\sigma_{\delta}$ & $N$ & satellite \\
\hline 1984-1986 & 0.0025 & 0.0240 & -0.0021 & 0.0175 & 34 & Ariel \\
Walker et al. (1988) & -0.0014 & 0.0236 & -0.0008 & 0.0284 & 33 & Umbriel \\
& -0.0039 & 0.0238 & 0.0032 & 0.0250 & 34 & Titania \\
& -0.0051 & 0.0210 & -0.0015 & 0.0288 & 34 & Oberon \\
& 0.0668 & 0.0771 & 0.0096 & 0.1348 & 4 & Miranda \\
\hline 1981-1985 & -0.0050 & 0.1149 & 0.0523 & 0.0779 & 76 & Miranda \\
Pascu et al. (1987) & & & & & & \\
\hline 1979-1983 & -0.0024 & 0.0384 & 0.0052 & 0.0424 & 88 & Ariel \\
Harrington et al. (1984) & -0.0014 & 0.0525 & -0.0005 & 0.0528 & 85 & Umbriel \\
& 0.0070 & 0.0417 & 0.0043 & 0.0368 & 86 & Titania \\
& 0.0010 & 0.0446 & 0.0023 & 0.0478 & 88 & Oberon \\
& -0.0118 & 0.1032 & -0.0330 & 0.0907 & 30 & Miranda \\
\hline 1977-1982 & -0.0042 & 0.0583 & 0.0047 & 0.0622 & 343 & Ariel \\
Veillet (1983) & 0.0020 & 0.0627 & 0.0004 & 0.0635 & 340 & Umbriel \\
& -0.0049 & 0.0506 & 0.0046 & 0.0575 & 343 & Titania \\
& -0.0122 & 0.0459 & -0.0004 & 0.0556 & 345 & Oberon \\
& 0.0290 & 0.0997 & -0.0138 & 0.0926 & 230 & Miranda \\
\hline 1981 & -0.0070 & 0.1136 & -0.0436 & 0.1144 & 78 & Miranda \\
Veillet (1983) & & & & & & \\
\hline 1975-1977 & 0.0231 & 0.0813 & -0.0092 & 0.0761 & 28 & Ariel \\
Walker et al. (1978) & 0.0111 & 0.0707 & 0.0196 & 0.0711 & 28 & Umbriel \\
& -0.0081 & 0.1031 & -0.0051 & 0.0734 & 28 & Titania \\
& 0.0021 & 0.0989 & 0.0090 & 0.1066 & 28 & Oberon \\
& -0.0145 & 0.2755 & -0.0293 & 0.1924 & 26 & Miranda \\
\hline 1948-1964 & -0.0146 & 0.1429 & -0.0039 & 0.2240 & 91 & Ariel \\
Van Biesbroek (1970) & -0.0006 & 0.1084 & -0.0056 & 0.1531 & 108 & Umbriel \\
& -0.0195 & 0.0918 & 0.0173 & 0.1067 & 111 & Titania \\
& 0.0199 & 0.1174 & 0.0131 & 0.1712 & 107 & Oberon \\
& 0.0254 & 0.1713 & -0.0422 & 0.2349 & 56 & Miranda \\
\hline & & & & & &
\end{tabular}

Table 4. Values of the mean $v$ and standard deviations $\sigma$ on right ascension and declination in kilometer for each satellite residuals, $N$ being the number of observations used by satellite.

\begin{tabular}{lccccrl}
\hline \hline Observations & $v_{\alpha}$ & $\sigma_{\alpha}$ & $v_{\delta}$ & $\sigma_{\delta}$ & \multicolumn{1}{c}{$N$} & Satellite \\
\hline Voyager spacecraft & 5.7127 & 167.9445 & -17.8164 & 126.0864 & 104 & Ariel \\
& -6.9729 & 123.4155 & -36.7124 & 176.7181 & 103 & Umbriel \\
& 7.5183 & 169.6452 & -18.7155 & 144.8990 & 66 & Titania \\
& -43.2894 & 298.7594 & 64.9974 & 257.9211 & 64 & Oberon \\
& -76.9123 & 222.9315 & -73.5024 & 248.1126 & 102 & Miranda \\
\hline
\end{tabular}


Table 5. Albedoes used for the calculation of the magnitude drop.

\begin{tabular}{llll}
\hline \hline & Satellites & $V$-band & $R$-band \\
\hline U-5 & Miranda & 0.307 & 0.310 \\
U-1 & Ariel & 0.350 & 0.374 \\
U-2 & Umbriel & 0.189 & 0.185 \\
U-3 & Titania & 0.232 & 0.234 \\
U-4 & Oberon & 0.205 & 0.230 \\
\hline
\end{tabular}

of the cones and the satellites are calculated carefully taking the light-time into account. In some cases, the relative velocity of the two satellites or of the eclipsed satellite with reference to the cones is very small or has non linear variations. This induces some errors in determining the times of the beginning and end of these events.

The magnitude drops are provided in several forms: first the flux drop in units of flux $(0=$ no decrease of light; $1=$ total disappearance of the object) and second in magnitude units that more understandable for human eyes $(0=$ no decrease of light, unchanged magnitude of the object(s); $n=$ increase in magnitude at the maximum of the event). We calculated the drop depending on the albedoes of the implied satellites in the bands $V$ and $R$, which are commonly used by observers. Table 5 provides the values used for the albedoes. Note the strong difference between Ariel and Umbriel leading to a large influence on the flux drop. These values are deduced from the papers by Helfenstein et al. (1988), Buratti et al. (1990, 1991), and Karkoshka $(1997,2001)$.

\subsection{The data}

The predictions of the mutual events were made using the two models LA06 and GUST86 and are available in electronic form on the CDS server and also on the web site of the IMCCE at the address ftp://ftp.imcce.fr/pub/ephem/satel /pheura07. Tables 7-18 provide the data for the best events, the most observable, first for LA06 and second for GUST86. Tables 19 to 27, available in an electronic form and also at the ftp address above, provide more events that may not occur since they are not predicted by both ephemerides LA06 and GUST86. One will be able to see the discrepancies in the predictions. These last tables provide the data as follows:

Cols. 1-3: date of the maximum of the event.

Cols. 4-6: nature of the event: 1 OC 2 means that satellite 1 occults satellite 2, while 3 EC 4 means that satellite 3 eclipses satellite 4 , etc.

Col. 7: $\mathrm{P}$ stands for partial, A for annular, $\mathrm{T}$ for total, $\mathrm{p}$ for eclipse by the penumbra, and $\mathrm{c}$ for conjunction.

Cols. 8-10: $\mathrm{h}, \mathrm{min}, \mathrm{s}$ in TT of the maximum of the event calculated with LA06 ephemeris.

Cols. 11-13: h, min, s in TT of the maximum of the event calculated with GUST86 ephemeris.

Col. 14: apparent separation from the occulted or eclipsed satellite to the limb of Uranus in uranian radii.

Since the inclinations of the orbital planes are not well known, because the observations used to build the theories we mainly performed when the Uranian system was observed from its pole, the grazing events are not certain to be grazing! They might well be deep events or non existent... Note that an event occurs or not, depending on an error in the apparent separation of about 0.01 arcsec, since the errors on the ephemerides is more likely 0.1 arcsec! As a result, the possible events are events calculated by including the possibility of such an error on the positions of the satellites.

The data of Tables 7 to 18 (more probable events) are as follows:

Cols. 1-3: date of the maximum of the event;

Cols. 4-6: nature of the event: 1 OC 2 means that satellite 1 occults satellite 2, while 3 EC 4 means that satellite 3 eclipses satellite 4 , etc.

Col. 7: P stands for partial, A for annular, T for total, $\mathrm{p}$ for eclipse by the penumbra and $\mathrm{c}$ for conjunction.

Cols. 8-10: h, min, $\mathrm{s}$ in UTC of the beginning of the occultation or of the eclipse by the penumbra.

Cols. 11-13: h, min, $\mathrm{s}$ in TT of the maximum of the event.

Col. 14: duration of the event in seconds; duration of the eclipse by the shadow; no duration is indicated for grazing events or an eclipse by the penumbra.

Col. 15: apparent distance from the occulted or eclipsed satellite to the limb of Uranus in Uranian radii.

Col. 16: flux drop in unit of flux in the $R$-band $(0=$ no flux drop; $1=$ disappearance of the object); the flux drop is calculated relative to both implied satellites for occultation and to only the eclipsed satellite for the eclipses.

Col. 17: magnitude drop in magnitude unit in the $R$-band $(0=$ no magnitude drop; $n=$ increase in the magnitude) for both implied satellites together for occultations and only for the eclipsed satellite for eclipses.

Col. 18: magnitude drop in magnitude unit in the $R$-band $(0=$ no magnitude drop; $n=$ increase in the magnitude) for both implied satellites together either for occultations and for the eclipses.

Col. 19: magnitude drop in magnitude unit in the $V$-band $(0=$ no magnitude drop; $n=$ increase in the magnitude) for both satellites together for occultations and for only the eclipsed satellite for the eclipses.

Col. 20: magnitude drop in magnitude unit without albedo corrections $(0=$ no magnitude drop; $n=$ increase in the magnitude $)$ for both satellites together for occultations and for only the eclipsed satellite for the eclipses.

Col. 21: impact parameter in arcsec.

Note that for total eclipses, the magnitude drop is infinite, so we put asterisks in the tables in that case.

The dates are provided in terrestrial time (TT) since the UTC for this period is not available yet. The difference TT - UTC will, however, be nearly $66 \mathrm{~s}$ in 2006 . Note that observations will be recorded with reference to UTC, so don't forget to subtract $66 \mathrm{~s}$ of time from the predicted times - if $66 \mathrm{~s}$ is confirmed - to get the observing time. In any case, due to the uncertainties in the ephemerides, start at least $15 \mathrm{~min}$ before the beginning of the event.

The predictions of the events are available for the two models, first for LA06 and second for GUST86. The comparison between the two ephemerides leads to several conclusions:

- the deviation between LA06 and GUST86 may reach $500 \mathrm{~km}$ (0.04 arcsec) either in longitude (change in the midtime of 
the event) or in latitude (change in the magnitude drop of the event);

- most of the events have their midtimes predicted within 5 min of time with LA06 and GUST86, but some larger differences may occur for singular configurations of the satellites (for example, 30 min of time for the occultation of U-2 by U-1 on August 25, 2007);

- among the main events, 11 events predicted using LA06 are not seen using GUST86 and many events have a difference of $50 \%$ for their flux drop.

The only observation of some events (they occur or not) will be sufficient to provide information on the relative inclinations of the orbits. A more complete analysis of the differences between LA and GUST is provided in Arlot \& Lainey (2006). In the next subsections, we provide more information on the visibility and on the observability of these events.

\subsection{The visibility and observability of the events}

Since they occur anytime and since their duration is, usually, only a few minutes long, the events are observable only from selected sites where Uranus is visible. The declination of Uranus during the occurrence of the mutual events will be near -4 to -8 degrees. Therefore, the observations will be slightly easier in the Southern hemisphere but also observable in the Northern one. Table 6 provides the number of events observable from some selected sites around the world. We considered that an event is observable when the Sun is more than 10 degrees under the horizon and Uranus is more than 15 degrees above the horizon and the satellites at more than one Uranian radius from the limb of the planet.

Note that grazing events (Col. 2) may be observable or not because of the sensitivity of these events to the inclinations of the orbital planes of the satellites. We considered that an event is grazing only when its observability depends on the possible error in the ephemerides. Thus, if a signal is detected during such an event, one will get valuable information. Note also that the total or annular events will present light curves with a flat step allowing analysis of the scattering law of the light on the surfaces of the satellites. Short events or faint events (the magnitude of which is less than ten percent) will be difficult to catch because of the low signal-to-noise ratio, and observers will need near perfect photometric conditions. The long events (one hour or more) are interesting too, but the observers must take the changing elevation of Uranus on the sky into account: the event must end before Uranus sets. The observers may be aware that the predicted times may have an error of several minutes in some cases. This difference between the observation and the prediction contains useful information for improving the theoretical models of the satellite motions. Therefore, the observations must start at least $15 \mathrm{~min}$ (or more for long events) before the predicted beginning and must be referred to UTC within one tenth of a second. The predictions are made from the center of the Earth. Since the events are topocentric, we should have to make corrections for the diurnal parallax. However, due to the distance between the Earth and the Uranian satellites, this correction is negligible.

Will we be certain we will observe the events? The comparison of the different sets of predictions may give information on the uncertainties. Christou (2005) published predictions using GUST86 and obtained results similar to ours within a few tenths of a second of time, which shows that we used similar models for the phenomena. Our results using the LA06 model show some discrepancies that may reach $30 \mathrm{~min}$ for the timing and $50 \%$
Table 6. Visibility of the mutual events depending on the site of observation.

\begin{tabular}{lll}
\hline \hline Observatory & $(1)$ & $(2)$ \\
\hline Cape Town (South Africa) & 68 & 26 \\
Siding Spring (Australia) & 62 & 25 \\
Catania (Italy) & 61 & 25 \\
Brasopolis (Brazil) & 57 & 17 \\
Barcelona (Spain) & 56 & 20 \\
ESO-La Silla (Chile) & 55 & 21 \\
Pic du Midi (France) & 53 & 19 \\
Kavalur (India) & 52 & 25 \\
Purple Mountain (China) & 52 & 24 \\
Haute-Provence (France) & 52 & 21 \\
Nauchny (Ukraine) & 52 & 21 \\
Mauna Kea, Hawaii (USA) & 52 & 19 \\
Mc Donald (USA) & 52 & 18 \\
Bucarest (Romania) & 51 & 25 \\
Stuttgart (Germany) & 51 & 22 \\
Torino (Italy) & 51 & 21 \\
Canarian Islands (Spain) & 51 & 12 \\
Zelenchuk (Russia) & 50 & 22 \\
Buenos-Aires (Argentina) & 50 & 17 \\
Paris (France) & 48 & 19 \\
Uccle (Belgium) & 48 & 19 \\
Dodaira (Japan) & 48 & 18 \\
Pekin (China) & 47 & 20 \\
Berlin (Germany) & 45 & 19 \\
Washington DC (USA) & 43 & 17 \\
Topeka Kansas (USA) & 39 & 13 \\
Moscow (Russia) & 38 & 20 \\
\hline
\end{tabular}

(1): All events, even grazing; (2): events easily observable occurring at more than one Uranian radius from the limb of the planet.

for the magnitude drop. Therefore, some events predicted with GUST86 are not predicted by LA06 and vice versa. This shows the interest of these observations: the magnitude drop should be measured carefully in order to deduce data on the inclinations of the orbits of the satellites.

Information on the visibility of the events from any site of observation is provided on the web site of IMCCE at the address given below.

\section{The observations of the mutual events}

Observation of the mutual events consists in recording the light flux as a function of time using a photometric receptor. At present, CCDs are the most common detectors used for this type of observation. Note that the Uranian satellites have such a magnitude that the observation is not easy and it needs a large telescope (at least an aperture of $60 \mathrm{~cm}$ ). Miranda has a magnitude of 16.5, Ariel 14.4, Umbriel 14.8, Titania 13.8, and Oberon 14.2. In order to have a good signal-to-noise ratio, each frame should have an exposure time around $5 \mathrm{~s}$ with a $1 \mathrm{~m}$ telescope. Intensified cameras may help to decrease the time exposure but will degrade the photometric accuracy. Then, short events needing shorter frames will be observable only with larger telescopes.

Each image must be dated in UTC within an accuracy of $0.1 \mathrm{~s}$ that corresponds, according to the velocities of the satellites, to an astrometric accuracy on the order of $1 \mathrm{~km}$ for the relative position of the satellites (corresponds to 0.1 mas in geocentric position).

The advantage of two-dimensional receptors is the possibility of getting several satellites in the field. This will help 
for the photometric reduction, as we will see below. Other types of detectors may be used, such as single-channel photoelectric photometers for fast photometry in several spectral bands. Photographic or visual observations will not be possible. Technical notes on the use of several types of detectors are available by request from the authors or on the web server of IMCCE at the address given below.

Most of time, the raw light-curves are difficult to analyze without a specific photometric reduction. Since we only need relative photometry the recorded magnitude drop is measured in reference to the magnitude of the satellites before and after the event. However, it is important to record a reference object not affected by the event at the same time. Using a two-dimensional receptor will allow the observer to simultaneously record both the satellites involved in the event and another uninvolved satellite with constant brightness. Only for long events it will be necessary to take the rotation of the satellites into account. A two-dimensional detector will also record the sky background simultaneously. Then, the reduction will easily solve the problems related to light clouds or to the variation in the elevation of the observed bodies in the sky, as well as to the brightness of the sky background before sunrise or after sunset. If using a single-channel receptor, the observer will need to alternatively record the sky background and a reference object either during the event for a long event (more than $20 \mathrm{~min}$ ) or just before and after the event for a short event. One should consult the technical notes explaining how to perform this calibration (Arlot 2002).

In order to optimize the observations and to catch the maximum number of phenomena, we propose to organize a campaign of observations so as to coordinate the observing sites as we did for the Galilean and Saturnian satellites. Such campaigns, as organized in the past, allowed publication of a very complete catalogue of data such as in Arlot et al. (1997) for the 1991 occurrence and in Arlot et al. (2005) and Emelianov et al. (2000) for the 1997 occurrence. The reader is encouraged to join our campaign of observations, to contact the authors at arlot@imcce.fr, and to get information on the campaign of observations from the web address www. imcce. fr/pheura07.

\section{The interest of the observations}

\subsection{Astrometry and dynamics of the Uranian satellites: the accuracy}

The goal of the observation of the mutual phenomena of the Uranian satellites is to obtain astrometric data leading to relative positions of the satellites with high accuracy. Observations of the mutual events have been shown to be more accurate than direct photographic or CCD ones. Measurement of the magnitude drop at the time of the minimum distance corresponds to the time of this minimum distance. Thanks to the absence of an atmosphere on the satellites, we will appreciate the sharpness of the light curves. The mutual events should easily lead to a positional accuracy of at least $100 \mathrm{~km}$, i.e. an astrometric geocentric accuracy of 10 mas.

The accuracy of the observations of the mutual events does not depend on the distance of the observed objects, in contrast to direct astrometric observations whose accuracy in angle (arcsec) corresponds to larger separations near Uranus than near Jupiter. However, the Uranian satellites are fainter than the Jovian ones, so it will be necessary to use larger telescopes that provide a good signal-to-noise ratio in order to get the same astrometric accuracy than for the Jovian satellites.
Such observed positions help to fit the dynamical models of the motions of the satellites. Their accuracy allows better determination of the inclinations and eccentricities. The Voyager 2 spacecraft has some precise observations, but during too short an interval of time to be able to determine orbital parameters with sufficient acuracy. For that, we need accurate observations over a long interval of time as provided by the mutual events together with ground-based observations since 1787 . These events have never been observed and are a challenge for the next years.

\subsection{Planetology: analysis of the surfaces and constraints on the internal structures}

Looking for a better reduction of the mutual phenomena of the Galilean satellites, Vasundhara et al. (1996) demonstrated that a new reduction considering that the satellites are not uniform disks may help to improve the accuracy of the data. Surface effects were suspected to be non-negligible when observing the mutual events presenting light curves with an asymmetrical aspect. Taking the surface effects into account for the reduction allows the determination of unknowns related to planetological parameters, such as the porosity and the rugosity of the surfaces of the satellites themselves, implying different scattering laws affecting the observed light curves.

On the other hand, our dynamical model LA06 contains parameters depending on tidal effects on the satellites, which may be fit thanks to new accurate data such as observations of mutual events. This may provide constraints on the internal structure of the satellites.

\section{Conclusion}

The occurrence of the mutual events in 2006-2009 is particularly favorable because of the opposition of Uranus when the mutual events are the most numerous (i.e., when the uranocentric declination of the Sun and the Earth is at a minimum). We encourage observers to make the most of their observations during this occurrence in order to complete the collections of groundbased data. Such events are very promising after experiences with similar events occurring in the Jovian and Saturnian systems. Moreover, valuable information on the inclination of the orbits of the satellites will be deduced from these events. We look forward to performing observations so as to obtain highly accurate astrometric data.

Acknowledgements. These calculations were made possible thanks to the CNRS (Centre National de la Recherche Scientifique) and the Institut de mecanique céleste/Observatoire de Paris.

\section{References}

Arlot, J. E. 1999, Proc. of the 5th workshop PHEMU97, held in Catania, Italy on March 4-6, 1997, ed. J.-E. Arlot, \& C. Blanco (Paris: IMC Éditions), 59 Arlot, J. E. 2002, Technical notes Phemu (Paris: IMCCE)

Arlot, J.-E., Ruatti, C., Thuillot, W., et al. 1997, A\&AS, 125, 399

Buratti, B., \& Mosher, J. 1991, Icarus, 90, 1

Buratti, B., Wong, F., \& Mosher, J. 1990, Icarus, 84, 203

Chanturya, Kisseleva, Emalianov: 2002, Izvestia Pulkovo, 216349

Christou, A. 2005, Icarus, 178, 171

Emelianov, N. V., \& Berejnoi, A. A., Vashkovjak, S. N., et al. 2000, A\&AS, 141, 433

Harrington, R. S., \& Walker, R. L. 1984, AJ, 89, 889

Helfenstein, P., Veverka, J., \& Thomas, P. C. 1988, Icarus, 74, 231

Jacobson, R. A. 1992, A\&AS, 96, 549

Jacobson, R. A., Campbell, J. K., Taylor, A. H., \& Synnott, S. P. 1992, The masses of Uranus and its major satellites from Voyager tracking data and earth-based Uranian satellite data, AJ, 103, 2068 
Karkoschka, E. 1997, Icarus, 125, 348

Karkoschka, E. 2001, Icarus, 151, 51

Lainey, V., \& Arlot, J. E. 2006, New ephemerides of the Uranian satellites, A\&A, in preparation

Lainey, V., Dehant, V., \& Pätzold, M. 2006, First numerical ephemerides of the Martian moons, A\&A, submitted

Laskar, J. 1986, A general theory for the Uranian satellites, A\&A, 166, 349

Laskar, J., \& Jacobson, R. A. 1987, GUST86 - an analytical ephemeris of the Uranian satellites, A\&A, 188, 212

Lainey, V., \& Arlot, J. E. 2006, Eclipses of the satellites of Uranus in 2006-2009, in preparation

McNaught, R. H., \& Garradd, G. J. 2003, NSDC Comm. UM008

Owen, W. M. 1999 and 2001, NSDC Comm. UM004 and UM005

Pascu, D., Seidelmann, P. K., Schmidt, R. E., Santos, E. Y., \& Hershey, Y. L. 1987, AJ, 93, 963

Seidelmann, P. K., Abalakin, V. K., Bursa, M., et al. 2002, Celes. Mech., 82, 83
Standish, E. 1998, JPL Internal memorandum

Stone, R. C. 2000, AJ, 120, 2124

Stone, R. C. 2001, AJ, 122, 2723

Stone, R. C., \& Harris, A. 2000, AJ, 119, 1985

Taylor, D. B. 1998, A\&A, 330, 362

Thuillot, W., et al. 2006, Infrared observations of eclipsed satellites of Uranus, in preparation

Van Biesbroek, G. 1970, Comm. to Lunar and Planetary laboratory, 8, 179

Vasundhara, R., Arlot, J.-E., \& Descamps, P. 1996, Proc., 172, IAU Symp., ed. S. Ferraz Mello, B. Morando, \& J.-E. Arlot (Kluwer Acad. Pub.), 423

Veiga, C. H., Martins, R. V., Veillet, C., \& Lazzaro, D. 1987, A\&AS, 70, 325

Veiga, C. H., Vieira Martins, R., \& Andrei, A. H. 2003, AJ, 125, 2714

Veillet, C. 1983, Ph.D. University of Paris VI

Walker, R. L., \& Harrington, R. S. 1988, AJ, 95, 1562

Walker, R. L., Christy, J. W., \& Harrington, R. S. 1978, AJ, 83, 838 


\section{Online Material}


J.-E. Arlot et al.: Mutual events of the Uranian satellites, Online Material $p 2$

Table 7. Mutual events of the 2006-2008 period: main events predicted with LA06 (1/6).

\begin{tabular}{|c|c|c|c|c|c|c|c|c|c|c|c|}
\hline $\begin{array}{l}\text { Date (TT) } \\
\text { of maximum } \\
\text { year mth day } \\
\text { Cols. }\left(\begin{array}{lll}1 & 2 & 3\end{array}\right)\end{array}$ & $\begin{array}{l}\text { Event } \\
\text { (4 } 567 \text { ) }\end{array}$ & $\begin{array}{l}\text { Begins } \\
\text { at } \\
\text { h m s } \\
(8910)\end{array}$ & $\begin{array}{l}\mathrm{h} \mathrm{m} \mathrm{s} \\
(111213)\end{array}$ & $\begin{array}{l}\text { Dur. } \\
\text { s } \\
\text { (14) }\end{array}$ & $\begin{array}{l}\text { Dist. } \\
\text { (UR) } \\
\text { (15) }\end{array}$ & $\begin{array}{l}\text { Flux } \\
R \\
(16)\end{array}$ & $\begin{array}{l}\text { Magn. } \\
R \\
(17)\end{array}$ & $\begin{array}{l}\text { Magn. } \\
R \\
2 \text { sat } \\
(18)\end{array}$ & $\begin{array}{l}\text { Magn. } \\
V \\
(19)\end{array}$ & $\begin{array}{l}\text { Magn. } \\
\text { no alb. } \\
(20)\end{array}$ & $\begin{array}{l}\text { Impact } \\
\text { param. } \\
\left({ }^{\prime \prime}\right) \\
(21)\end{array}$ \\
\hline 200655 & $5 \mathrm{OC} 1 \mathrm{P}$ & 10235 & 102641 & 432 & 3.9 & 0.157 & 0.185 & 0.185 & 0.172 & 0.101 & 0.035 \\
\hline 2006511 & $1 \mathrm{OC} 5 \mathrm{P}$ & 173410 . & 173619 . & 259 & 3.9 & 0.072 & 0.081 & 0.081 & 0.085 & 0.091 & 0.037 \\
\hline 200663 & 1 OC $5 \mathrm{P}$ & 10457. & 10843 & 451 & 3.8 & 0.062 & 0.069 & 0.069 & 0.073 & 0.078 & 0.039 \\
\hline 2006616 & $1 \mathrm{OC} 5 \mathrm{~T}$ & 0379. & 03914 . & 251 & 3.8 & 0.130 & 0.152 & 0.152 & 0.160 & 0.171 & 0.001 \\
\hline 2006622 & $5 \mathrm{OC} 1 \mathrm{P}$ & 81920. & 82041. & 161 & 3.4 & 0.122 & 0.142 & 0.142 & 0.132 & 0.078 & 0.040 \\
\hline 200672 & $5 \mathrm{OC} 1 \mathrm{~A}$ & 9413. & 94640 & 674 & 3.7 & 0.256 & 0.322 & 0.322 & 0.298 & 0.171 & 0.018 \\
\hline 200678 & 1 OC $5 \mathrm{P}$ & 163812. & 164054. & 323 & 4.0 & 0.110 & 0.126 & 0.126 & 0.133 & 0.142 & 0.031 \\
\hline 2006715 & $5 \mathrm{OC} 1 \mathrm{P}$ & 0612 & 084 & 225 & 3.8 & 0.178 & 0.213 & 0.213 & 0.198 & 0.116 & 0.035 \\
\hline 2007310 & 1 OC $5 \mathrm{~T}$ & 43141 & 43356 . & 270 & 3.8 & 0.130 & 0.152 & 0.152 & 0.160 & 0.171 & 0.001 \\
\hline 2007316 & $5 \mathrm{OC} 1 \mathrm{P}$ & 121324 . & 121437. & 146 & 3.5 & 0.080 & 0.090 & 0.090 & 0.084 & 0.050 & 0.042 \\
\hline 2007325 & $1 \mathrm{OC} 5 \mathrm{~T}$ & 12172 & 12189. & 135 & 0.6 & 0.130 & 0.152 & 0.152 & 0.160 & 0.171 & 0.002 \\
\hline 2007326 & $5 \mathrm{OC} 1 \mathrm{P}$ & 135425 . & 14045 . & 760 & 3.6 & 0.227 & 0.279 & 0.279 & 0.259 & 0.150 & 0.027 \\
\hline 200741 & $1 \mathrm{EC} 5 \mathrm{P}$ & 203812 . & 204128 & 352 & 4.0 & 0.707 & 1.332 & 0.099 & 1.332 & 1.332 & 0.033 \\
\hline 200748 & $5 \mathrm{EC} 1 \mathrm{~A}$ & 4242 & 4532 & 314 & 3.8 & 0.163 & 0.193 & 0.167 & 0.193 & 0.193 & 0.009 \\
\hline 2007414 & $1 \mathrm{EC} 5 \mathrm{~T}$ & 114540 . & 11485 . & 262 & 3.6 & 1.000 & $* * * * *$ & 0.144 & $* * * * *$ & $* * *$ & 0.008 \\
\hline 2007420 & $5 \mathrm{EC} 1 \mathrm{~A}$ & 19337. & 193449 . & 177 & 3.1 & 0.163 & 0.193 & 0.167 & 0.193 & 0.193 & 0.019 \\
\hline 2007422 & $1 \mathrm{OC} 5 \mathrm{P}$ & 123640 . & 123758 . & 157 & 2.6 & 0.130 & 0.151 & 0.151 & 0.159 & 0.170 & 0.023 \\
\hline 2007424 & $2 \mathrm{OC} 1 \mathrm{P}$ & 62224 & 62720. & 592 & 6.2 & 0.084 & 0.095 & 0.095 & 0.092 & 0.070 & 0.060 \\
\hline 2007427 & 1 EC 5 P & 3270. & 32821 . & 152 & 2.8 & 0.707 & 1.334 & 0.100 & 1.334 & 1.334 & 0.032 \\
\hline 2007428 & $5 \mathrm{OC} 1 \mathrm{P}$ & 202943 . & 203059 . & 152 & 3.0 & 0.169 & 0.201 & 0.201 & 0.187 & 0.110 & 0.034 \\
\hline 2007430 & $1 \mathrm{OC} 2 \mathrm{P}$ & 112235 . & 112742 . & 613 & 6.2 & 0.241 & 0.300 & 0.300 & 0.321 & 0.491 & 0.017 \\
\hline 2007430 & 3 OC $2 \mathrm{~T}$ & 4405. & 4454 & 598 & 8.5 & 0.214 & 0.261 & 0.261 & 0.282 & 0.476 & 0.003 \\
\hline 2007430 & $5 \mathrm{EC} 1 \mathrm{~A}$ & 201026 . & 201427 . & 453 & 3.9 & 0.164 & 0.194 & 0.168 & 0.194 & 0.194 & 0.005 \\
\hline 200753 & $1 \mathrm{OC} 3 \mathrm{~A}$ & 2169. & 22546 & 1175 & 6.1 & 0.327 & 0.430 & 0.430 & 0.438 & 0.470 & 0.000 \\
\hline 200753 & $1 \mathrm{OC} 3 \mathrm{P}$ & 125058. & 13425 . & 1613 & 1.0 & 0.313 & 0.407 & 0.407 & 0.415 & 0.445 & 0.019 \\
\hline 200753 & $2 \mathrm{OC} 1 \mathrm{P}$ & 91231. & 91449. & 276 & 3.6 & 0.650 & 1.139 & 1.139 & 1.081 & 0.724 & 0.002 \\
\hline 200753 & $2 \mathrm{OC} 3 \mathrm{~A}$ & 83449 . & 83744 . & 350 & 3.2 & 0.329 & 0.434 & 0.434 & 0.442 & 0.476 & $0.010^{*}$ \\
\hline 200753 & $4 \mathrm{OC} 1 \mathrm{P}$ & 213616 . & 213846 . & 300 & 3.1 & 0.217 & 0.266 & 0.266 & 0.260 & 0.211 & 0.047 \\
\hline 200753 & $4 \mathrm{OC} 3 \mathrm{P}$ & 233944 . & 234335 . & 463 & 2.3 & 0.408 & 0.569 & 0.569 & 0.589 & 0.712 & 0.002 \\
\hline 200754 & $1 \mathrm{OC} 3 \mathrm{P}$ & 8612. & 8100 & 456 & 6.3 & 0.063 & 0.071 & 0.071 & 0.072 & 0.077 & 0.069 \\
\hline 200754 & $4 \mathrm{OC} 2 \mathrm{P}$ & 19753. & 191041. & 337 & 4.1 & 0.127 & 0.147 & 0.147 & 0.158 & 0.253 & 0.042 \\
\hline 200755 & $1 \mathrm{OC} 2 \mathrm{P}$ & 03553 . & 03732. & 197 & 0.8 & 0.111 & 0.128 & 0.128 & 0.136 & 0.199 & 0.043 \\
\hline 200756 & $2 \mathrm{OC} 1 \mathrm{P}$ & 17231 . & 17554. & 406 & 6.1 & 0.208 & 0.253 & 0.253 & 0.244 & 0.183 & 0.045 \\
\hline 200757 & 1 EC $5 \mathrm{P}$ & 33633 . & 33849 . & 233 & 3.9 & 0.427 & 0.604 & 0.059 & 0.604 & 0.604 & 0.040 \\
\hline 2007511 & $5 \mathrm{OC} 4 \mathrm{P}$ & 114437. & 11478 & 302 & 3.8 & 0.066 & 0.074 & 0.074 & 0.065 & 0.064 & 0.047 \\
\hline 2007529 & $1 \mathrm{EC} 5 \mathrm{~T}$ & 19472 & 195111. & 464 & 3.9 & 1.000 & $* * * * *$ & 0.144 & $* * * * *$ & $* * * * *$ & 0.017 \\
\hline
\end{tabular}


Table 8. Mutual events of the 2006-2008 period: main events predicted with LA06 (2/6).

\begin{tabular}{|c|c|c|c|c|c|c|c|c|c|c|c|}
\hline $\begin{array}{l}\text { Date (TT) } \\
\text { of maximum } \\
\text { year mth day } \\
\text { Cols. }\left(\begin{array}{lll}1 & 2 & 3\end{array}\right)\end{array}$ & $(45567)$ & $\begin{array}{l}\text { Begins } \\
\text { at } \\
\mathrm{h} \mathrm{m} \mathrm{s} \\
(8910)\end{array}$ & $\begin{array}{l}\mathrm{h} \mathrm{m} \mathrm{s} \\
\left(\begin{array}{lll}11 & 12\end{array}\right)\end{array}$ & $\begin{array}{l}\text { Dur. } \\
\text { s } \\
\text { (14) }\end{array}$ & $\begin{array}{l}\text { (UR) } \\
\text { (15) }\end{array}$ & $\begin{array}{l}\text { Flux } \\
R\end{array}$ & $\begin{array}{l}\text { Magn. } \\
R \\
(17)\end{array}$ & $\begin{array}{l}\text { Magn. } \\
R \\
2 \text { sat } \\
(18)\end{array}$ & $\begin{array}{l}\text { Magn. } \\
V\end{array}$ & $\begin{array}{l}\text { Magn. } \\
\text { no alb. } \\
\text { (20) }\end{array}$ & $\begin{array}{l}\text { Impact } \\
\text { param. } \\
\left({ }^{\prime \prime}\right) \\
(21)\end{array}$ \\
\hline 200761 & $1 \mathrm{EC} 5 \mathrm{P}$ & 104939. & 105051. & 85 & 2.4 & 0.114 & 0.131 & 0.015 & 0.131 & 0.131 & 0.050 \\
\hline 200767 & 5 EC $1 \mathrm{P}$ & 18452 & 18465 & 90 & 1.8 & 0.075 & 0.085 & 0.074 & 0.085 & 0.085 & 0.040 \\
\hline 2007614 & 1 EC $5 \mathrm{P}$ & 24320 . & 24427 . & 104 & 1.4 & 0.699 & 1.304 & 0.098 & 1.304 & 1.304 & 0.032 \\
\hline 2007620 & $5 \mathrm{EC} 1 \mathrm{~A}$ & 104049 . & 10422. & 119 & 0.7 & 0.164 & 0.194 & 0.168 & 0.194 & 0.194 & 0.019 \\
\hline 2007626 & $1 \mathrm{EC} 5 \mathrm{~T}$ & 184030 . & 184144. & 123 & 0.3 & 1.000 & $* * * * *$ & 0.144 & $* * * * *$ & $* * * * *$ & 0.011 \\
\hline 2007627 & 5 EC $1 \mathrm{P}$ & 192030 . & 192418. & 418 & 3.9 & 0.117 & 0.135 & 0.118 & 0.135 & 0.135 & 0.033 \\
\hline 2007629 & 2 EC $5 \mathrm{~T}$ & 19536. & 19754. & 236 & 3.5 & 1.000 & $* * * * *$ & 0.270 & $* * * * *$ & $* * * * *$ & 0.018 \\
\hline 200771 & 5 EC 2 A & 21182. & 211951. & 182 & 3.0 & 0.162 & 0.192 & 0.147 & 0.192 & 0.192 & 0.012 \\
\hline 200773 & $2 \mathrm{EC} 5 \mathrm{~T}$ & 233714 . & 233858 & 173 & 2.8 & 1.000 & $* * * * *$ & 0.270 & $* * * * *$ & $* * * * *$ & 0.001 \\
\hline 200776 & 5 EC 2 A & 15415 . & 15553. & 160 & 2.3 & 0.163 & 0.194 & 0.148 & 0.194 & 0.194 & 0.006 \\
\hline 200778 & $2 \mathrm{EC} 5 \mathrm{~T}$ & 41637. & 41810 & 153 & 2.1 & 1.000 & $* * * * *$ & 0.270 & $* * * * *$ & $* * * * *$ & 0.003 \\
\hline 2007710 & 5 EC 2 A & 63657 . & 63824 . & 139 & 1.6 & 0.164 & 0.195 & 0.149 & 0.195 & 0.195 & 0.015 \\
\hline 2007712 & $2 \mathrm{EC} 5 \mathrm{~T}$ & 9014. & 9137. & 132 & 1.3 & 1.000 & $* * * * *$ & 0.270 & $* * * * *$ & $* * * * *$ & 0.016 \\
\hline 2007712 & 5 OC $3 \mathrm{~A}$ & 33814 . & 34546 . & 890 & 1.3 & 0.099 & 0.113 & 0.113 & 0.111 & 0.096 & 0.004 \\
\hline 2007714 & $5 \mathrm{EC} 2 \mathrm{P}$ & 11235 . & 112415. & 99 & 0.8 & 0.112 & 0.129 & 0.099 & 0.129 & 0.129 & 0.034 \\
\hline 2007716 & 2 EC 5 P & 13471. & 13483. & 78 & 0.5 & 0.413 & 0.579 & 0.103 & 0.579 & 0.579 & 0.040 \\
\hline 2007722 & 1 EC $5 \mathrm{P}$ & 2393. & 23948 . & 82 & 0.2 & 0.153 & 0.180 & 0.021 & 0.180 & 0.180 & 0.048 \\
\hline 2007726 & 1 EC $5 \mathrm{P}$ & 185954. & 19331. & 381 & 3.9 & 0.384 & 0.526 & 0.053 & 0.526 & 0.526 & 0.041 \\
\hline 2007730 & 5 OC $4 \mathrm{P}$ & 1114. & 11825 . & 864 & 2.5 & 0.069 & 0.078 & 0.078 & 0.069 & 0.068 & 0.049 \\
\hline 200785 & 4 OC 2 P & 134330 . & 135710 . & 1682 & 8.5 & 0.075 & 0.084 & 0.084 & 0.090 & 0.142 & 0.061 \\
\hline 200786 & $1 \mathrm{OC} 5 \mathrm{~T}$ & 103419. & 103616. & 235 & 3.6 & 0.130 & 0.152 & 0.152 & 0.160 & 0.171 & 0.001 \\
\hline 200786 & 4 OC 2 P & 04833 . & 1825. & 2334 & 3.9 & 0.123 & 0.142 & 0.142 & 0.153 & 0.245 & 0.046 \\
\hline 2007813 & $1 \mathrm{OC} 2 \mathrm{P}$ & 3124. & 3638. & 627 & 6.3 & 0.264 & 0.333 & 0.333 & 0.356 & 0.551 & 0.014 \\
\hline 2007813 & $1 \mathrm{OC} 4 \mathrm{P}$ & 13235 . & 132530 . & 289 & 2.0 & 0.180 & 0.216 & 0.216 & 0.196 & 0.242 & 0.046 \\
\hline 2007814 & $2 \mathrm{OC} 1 \mathrm{P}$ & 20107. & 20124 . & 234 & 1.6 & 0.461 & 0.671 & 0.671 & 0.644 & 0.460 & 0.021 \\
\hline 2007814 & 2 OC 4 P & 13156. & 13449 . & 346 & 7.1 & 0.094 & 0.107 & 0.107 & 0.097 & 0.119 & 0.065 \\
\hline 2007814 & 2 OC $5 \mathrm{P}$ & 225556 . & 225734 . & 194 & 3.3 & 0.128 & 0.149 & 0.149 & 0.157 & 0.168 & 0.026 \\
\hline 2007815 & $2 \mathrm{OC} 3 \mathrm{~A}$ & 91257. & 91718. & 523 & 8.0 & 0.329 & 0.434 & 0.434 & 0.442 & 0.476 & 0.007 \\
\hline 2007816 & $1 \mathrm{OC} 2 \mathrm{P}$ & 11299. & 113120. & 262 & 2.9 & 0.322 & 0.422 & 0.422 & 0.453 & 0.722 & 0.002 \\
\hline 2007819 & $2 \mathrm{OC} 1 \mathrm{P}$ & 75258 . & 8017. & 877 & 6.2 & 0.318 & 0.415 & 0.415 & 0.400 & 0.295 & 0.036 \\
\hline 2007820 & 5 OC $2 \mathrm{P}$ & 135143. & 135846. & 879 & 3.5 & 0.103 & 0.118 & 0.118 & 0.121 & 0.137 & 0.032 \\
\hline
\end{tabular}


J.-E. Arlot et al.: Mutual events of the Uranian satellites, Online Material $p 4$

Table 9. Mutual events of the 2006-2008 period: main events predicted with LA06 (3/6).

\begin{tabular}{|c|c|c|c|c|c|c|c|c|c|c|c|}
\hline $\begin{array}{l}\text { Date (TT) } \\
\text { of maximum } \\
\text { year mth day } \\
\text { Cols. }\left(\begin{array}{lll}1 & 2 & 3\end{array}\right)\end{array}$ & $(4567)$ & 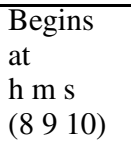 & $\begin{array}{l}\mathrm{h} \mathrm{m} \mathrm{s} \\
\left(\begin{array}{lll}1 & 12 & 13\end{array}\right)\end{array}$ & $\begin{array}{l}\text { Dur. } \\
\text { s } \\
\text { (14) }\end{array}$ & $\begin{array}{l}\text { (UR) } \\
\text { (15) }\end{array}$ & $\begin{array}{l}\text { Flux } \\
R\end{array}$ & $\begin{array}{l}\text { Magn. } \\
R \\
(17)\end{array}$ & $\begin{array}{l}\text { Magn. } \\
R \\
2 \text { sat } \\
(18)\end{array}$ & $\begin{array}{l}\text { Magn. } \\
V\end{array}$ & $\begin{array}{l}\text { Magn. } \\
\text { no alb. } \\
\text { (20) }\end{array}$ & $\begin{array}{l}\text { Impact } \\
\text { param. } \\
\left({ }^{\prime \prime}\right) \\
(21)\end{array}$ \\
\hline 2007822 & $2 \mathrm{EC} 5 \mathrm{~T}$ & 145940. & 15354 & 450 & 3.9 & 1.000 & ****** & 0.270 & ****** & ****** & 0.014 \\
\hline 2007824 & $1 \mathrm{OC} 2 \mathrm{P}$ & 121712 . & 122347 . & 790 & 6.1 & 0.080 & 0.091 & 0.091 & 0.096 & 0.140 & 0.054 \\
\hline 2007824 & 5 EC $3 \mathrm{~A}$ & 134140 . & 134415 . & 228 & 2.7 & 0.096 & 0.110 & 0.097 & 0.110 & 0.110 & 0.026 \\
\hline 2007825 & $1 \mathrm{OC} 2 \mathrm{P}$ & 65050 & 73543. & 13073 & 3.2 & 0.095 & 0.108 & 0.108 & 0.115 & 0.167 & 0.050 \\
\hline 200791 & 5 EC $1 \mathrm{P}$ & 1864. & 1876. & 93 & 1.2 & 0.097 & 0.110 & 0.096 & 0.110 & 0.110 & 0.036 \\
\hline 200796 & 3 EC $5 \mathrm{~T}$ & 202542 . & 202728 . & 157 & 0.1 & 1.000 & $* * * * *$ & 0.126 & $* * * * *$ & $* * * * *$ & 0.028 \\
\hline 200798 & $1 \mathrm{EC} 5 \mathrm{~T}$ & 2439. & 261. & 139 & 1.7 & 1.000 & $* * * * *$ & 0.144 & $* * * * *$ & $* * * * *$ & 0.009 \\
\hline 2007914 & 5 EC $1 \mathrm{P}$ & 1021 . & 10315 . & 119 & 2.3 & 0.124 & 0.144 & 0.125 & 0.144 & 0.144 & 0.032 \\
\hline 2007922 & 1 EC 5 P & 182226 . & 182726 . & 550 & 3.8 & 0.651 & 1.142 & 0.091 & 1.142 & 1.142 & 0.034 \\
\hline 2007929 & 5 OC $1 \mathrm{P}$ & 12020 & 12211. & 221 & 3.9 & 0.067 & 0.075 & 0.075 & 0.070 & 0.042 & 0.048 \\
\hline 2007107 & $2 \mathrm{EC} 5 \mathrm{~T}$ & 18023. & 18154. & 148 & 2.1 & 1.000 & $* * * * *$ & 0.270 & $* * * * *$ & $* * * * *$ & 0.013 \\
\hline 2007108 & 1 OC $5 \mathrm{~T}$ & 04256 . & 04412 . & 152 & 1.7 & 0.130 & 0.152 & 0.152 & 0.160 & 0.171 & 0.002 \\
\hline 2007109 & 5 EC 2 P & 20232 . & 202423 . & 139 & 2.5 & 0.110 & 0.126 & 0.097 & 0.126 & 0.126 & 0.034 \\
\hline 20071011 & $5 \mathrm{OC} 1 \mathrm{~A}$ & 16363. & 163752. & 219 & 3.5 & 0.257 & 0.322 & 0.322 & 0.298 & 0.171 & 0.017 \\
\hline 20071012 & 3 EC $5 \mathrm{~T}$ & 0125 . & 0325 . & 179 & 1.9 & 1.000 & $* * * * *$ & 0.126 & $* * * * *$ & $* * * * *$ & 0.027 \\
\hline 20071012 & 4 EC $5 \mathrm{~T}$ & 94835 . & 95215. & 332 & 3.6 & 1.000 & $* * * * *$ & 0.137 & $* * * * *$ & $* * * * *$ & 0.019 \\
\hline 20071018 & 1 OC $5 \mathrm{P}$ & 02821 . & 02935 . & 148 & 3.1 & 0.071 & 0.080 & 0.080 & 0.084 & 0.090 & 0.039 \\
\hline 20071021 & 1 EC 2 P & 22467 & 23459 . & 2138 & 0.5 & 0.211 & 0.257 & 0.079 & 0.257 & 0.257 & 0.054 \\
\hline 20071021 & $5 \mathrm{EC} 1 \mathrm{~A}$ & 18650. & 181328 & 754 & 3.7 & 0.165 & 0.196 & 0.169 & 0.196 & 0.196 & 0.017 \\
\hline 20071026 & $1 \mathrm{EC} 5 \mathrm{~T}$ & 12541 . & 12724. & 180 & 3.1 & 1.000 & $* * * * *$ & 0.144 & $* * * * *$ & $* * * * *$ & 0.010 \\
\hline 2007112 & 5 EC $3 \mathrm{~A}$ & 203024 . & 203248 . & 244 & 2.8 & 0.096 & 0.109 & 0.097 & 0.109 & 0.109 & 0.016 \\
\hline 20071111 & 1 EC 3 P & 25830 & 3824 & 998 & 0.6 & 0.114 & 0.132 & 0.069 & 0.132 & 0.132 & 0.069 \\
\hline 20071119 & $1 \mathrm{EC} 5 \mathrm{~T}$ & 1821. & 18109. & 924 & 3.6 & 1.000 & $* * * * *$ & 0.144 & $* * * * *$ & $* * * * *$ & 0.017 \\
\hline 20071121 & $2 \mathrm{EC} 1 \mathrm{P}$ & 164533 . & 164813. & 257 & 5.2 & 0.164 & 0.194 & 0.126 & 0.194 & 0.194 & 0.057 \\
\hline 20071123 & 4 EC 2 P & 55758. & 6234. & 190 & 9.1 & 0.063 & 0.071 & 0.022 & 0.071 & 0.071 & 0.082 \\
\hline 20071124 & 1 EC 2 P & 153437. & 153712 . & 239 & 5.3 & 0.125 & 0.145 & 0.046 & 0.145 & 0.145 & 0.061 \\
\hline 20071127 & 1 EC 2 P & 225112 & 22546. & 301 & 4.8 & 0.407 & 0.568 & 0.159 & 0.568 & 0.568 & 0.037 \\
\hline 20071128 & 1 EC 3 P & 13813. & 14220 . & 400 & 5.9 & 0.198 & 0.240 & 0.122 & 0.240 & 0.240 & 0.056 \\
\hline 20071129 & $2 \mathrm{EC} 3 \mathrm{~A}$ & 12447. & 125043. & 678 & 8.9 & 0.494 & 0.740 & 0.459 & 0.740 & 0.740 & 0.017 \\
\hline 20071129 & $2 \mathrm{EC} 4 \mathrm{P}$ & 19326. & 19716. & 277 & 7.3 & 0.119 & 0.137 & 0.091 & 0.137 & 0.137 & 0.067 \\
\hline 20071130 & 1 EC $5 \mathrm{P}$ & 85224 . & 85428. & 218 & 3.4 & 0.869 & 2.204 & 0.124 & 2.204 & 2.204 & 0.028 \\
\hline 20071130 & 2 EC $1 \mathrm{P}$ & 213241 . & 213617. & 386 & 5.7 & 0.453 & 0.656 & 0.390 & 0.656 & 0.656 & 0.035 \\
\hline
\end{tabular}


Table 10. Mutual events of the 2006-2008 period: main events predicted with LA06 (4/6).

\begin{tabular}{|c|c|c|c|c|c|c|c|c|c|c|c|}
\hline $\begin{array}{l}\text { Date (TT) } \\
\text { of maximum } \\
\text { year mth day } \\
\text { Cols. }\left(\begin{array}{lll}1 & 2 & 3\end{array}\right)\end{array}$ & $(4567)$ & $\begin{array}{l}\text { Begins } \\
\text { at } \\
\mathrm{h} \mathrm{m} \mathrm{s} \\
\left(\begin{array}{lll}8 & 9 & 10\end{array}\right)\end{array}$ & $\begin{array}{l}\mathrm{h} \mathrm{m} \mathrm{s} \\
(111213)\end{array}$ & $\begin{array}{l}\text { Dur. } \\
\text { s } \\
\text { (14) }\end{array}$ & $\begin{array}{l}\text { (UR) } \\
(15)\end{array}$ & $\begin{array}{l}\text { Flux } \\
R\end{array}$ & $\begin{array}{l}\text { Magn. } \\
R \\
(17)\end{array}$ & $\begin{array}{l}\text { Magn. } \\
R \\
2 \text { sat } \\
(18)\end{array}$ & $\begin{array}{l}\text { Magn. } \\
V\end{array}$ & $\begin{array}{l}\text { Magn. } \\
\text { no alb. } \\
\text { (20) }\end{array}$ & $\begin{array}{l}\text { Impact } \\
\text { param. } \\
\left({ }^{\prime \prime}\right) \\
(21)\end{array}$ \\
\hline 20071130 & $3 \mathrm{EC} 4 \mathrm{P}$ & 183534. & 184949 & 1473 & 15.6 & 0.729 & 1.419 & 0.465 & 1.419 & 1.419 & 0.023 \\
\hline 2007122 & 1 EC 2 P & 133753. & 133949 . & 186 & 0.2 & 0.459 & 0.667 & 0.181 & 0.667 & 0.667 & 0.033 \\
\hline 2007122 & 3 EC 2 P & 171250 . & 171545 . & 283 & 2.3 & 0.576 & 0.931 & 0.208 & 0.931 & 0.931 & 0.041 \\
\hline 2007123 & 3 EC $1 \mathrm{P}$ & 1251. & 1294. & 415 & 5.0 & 0.934 & 2.947 & 0.617 & 2.947 & 2.947 & 0.014 \\
\hline 2007124 & 2 EC $1 \mathrm{P}$ & 5343. & 5620. & 273 & 4.2 & 0.774 & 1.616 & 0.787 & 1.616 & 1.616 & 0.012 \\
\hline 2007126 & 4 EC $1 \mathrm{P}$ & 32118 . & 32443 . & 310 & 3.5 & 0.526 & 0.811 & 0.321 & 0.811 & 0.811 & 0.042 \\
\hline 2007126 & 4 EC 2 P & 6030 . & 6416. & 340 & 4.7 & 0.611 & 1.025 & 0.238 & 1.025 & 1.025 & 0.036 \\
\hline 2007126 & 4 EC 3 P & 135258 . & 13583. & 476 & 7.9 & 0.640 & 1.108 & 0.442 & 1.108 & 1.108 & 0.022 \\
\hline 2007127 & 1 EC 2 P & 3296. & 33339. & 494 & 6.0 & 0.756 & 1.532 & 0.316 & 1.532 & 1.532 & 0.014 \\
\hline 2007127 & 1 EC $3 \mathrm{P}$ & 13251. & 13533. & 256 & 1.3 & 0.394 & 0.544 & 0.257 & 0.544 & 0.544 & 0.031 \\
\hline 2007128 & $2 \mathrm{EC} 1 \mathrm{~A}$ & 195450. & 195657. & 214 & 0.8 & 0.814 & 1.824 & 0.847 & 1.824 & 1.824 & 0.002 \\
\hline 2007128 & 2 EC 3 P & 15451. & 15854. & 374 & 7.3 & 0.218 & 0.267 & 0.179 & 0.267 & 0.267 & 0.054 \\
\hline 20071210 & 1 EC 2 P & 11158. & 111735 . & 250 & 3.7 & 0.697 & 1.298 & 0.288 & 1.298 & 1.298 & 0.017 \\
\hline 20071211 & 3 EC $1 \mathrm{P}$ & 131332. & 131558. & 238 & 0.8 & 0.450 & 0.649 & 0.254 & 0.649 & 0.649 & 0.050 \\
\hline 20071211 & 3 EC 2 P & 44414 & 44741. & 353 & 4.9 & 0.880 & 2.304 & 0.337 & 2.304 & 2.304 & 0.018 \\
\hline 20071212 & $1 \mathrm{EC} 4 \mathrm{~A}$ & 144144 . & 144442 . & 275 & 1.0 & 0.557 & 0.883 & 0.365 & 0.883 & 0.883 & 0.002 \\
\hline 20071212 & $2 \mathrm{EC} 4 \mathrm{~A}$ & 163254. & 163614 . & 318 & 1.7 & 0.547 & 0.859 & 0.503 & 0.859 & 0.859 & 0.006 \\
\hline 20071212 & $3 \mathrm{EC} 4 \mathrm{~A}$ & 1616. & 1111. & 415 & 3.3 & 0.716 & 1.367 & 0.455 & 1.367 & 1.367 & 0.005 \\
\hline 20071213 & $2 \mathrm{EC} 1 \mathrm{~A}$ & 9512. & 91048. & 624 & 6.2 & 0.910 & 2.609 & 1.011 & 2.609 & 2.609 & 0.002 \\
\hline 20071215 & 1 EC 2 P & 21322 . & 21520 . & 189 & 1.5 & 0.425 & 0.601 & 0.166 & 0.601 & 0.601 & 0.036 \\
\hline 20071215 & 1 EC $3 \mathrm{P}$ & 14220. & 14533. & 302 & 4.7 & 0.180 & 0.216 & 0.110 & 0.216 & 0.216 & 0.059 \\
\hline 20071216 & 2 EC $1 P$ & 173150. & 173346. & 223 & 3.1 & 0.267 & 0.338 & 0.213 & 0.338 & 0.338 & 0.048 \\
\hline 20071217 & $2 \mathrm{EC} 5 \mathrm{~T}$ & 72948 & 73217. & 257 & 3.6 & 1.000 & $* * * * *$ & 0.270 & $* * * * *$ & $* * * * *$ & 0.016 \\
\hline 20071217 & 4 EC $3 \mathrm{~A}$ & 141350 . & 142124 . & 750 & 13.9 & 0.781 & 1.650 & 0.569 & 1.650 & 1.650 & 0.002 \\
\hline 20071219 & 1 EC 2 P & 141930 . & 142718 . & 869 & 6.2 & 0.790 & 1.693 & 0.332 & 1.693 & 1.693 & 0.012 \\
\hline 20071219 & 3 EC 2 P & 16408. & 164351. & 331 & 7.2 & 0.285 & 0.364 & 0.098 & 0.364 & 0.364 & 0.062 \\
\hline 20071221 & 2 EC $1 P$ & 82922. & 8316. & 130 & 2.2 & 0.072 & 0.081 & 0.053 & 0.081 & 0.081 & 0.067 \\
\hline 20071224 & $2 \mathrm{EC} 1 \mathrm{P}$ & 184627. & 18563. & 1082 & 6.1 & 0.472 & 0.694 & 0.410 & 0.694 & 0.694 & 0.034 \\
\hline
\end{tabular}


Table 11. Mutual events of the 2006-2008 period: main events predicted with LA06 (5/6).

\begin{tabular}{|c|c|c|c|c|c|c|c|c|c|c|c|}
\hline $\begin{array}{l}\text { Date (TT) } \\
\text { of maximum } \\
\text { year mth day } \\
\text { Cols. }\left(\begin{array}{llll}1 & 2 & 3\end{array}\right)\end{array}$ & $(4567)$ & $\begin{array}{l}\text { Begins } \\
\text { at } \\
\mathrm{h} \mathrm{m} \mathrm{s} \\
(8910)\end{array}$ & $\begin{array}{l}\mathrm{h} \mathrm{m} \mathrm{s} \\
(111213)\end{array}$ & $\begin{array}{l}\text { Dur. } \\
\text { s } \\
\text { (14) }\end{array}$ & $\begin{array}{l}\text { (UR) } \\
\text { (15) }\end{array}$ & $\begin{array}{l}\text { Flux } \\
R\end{array}$ & $\begin{array}{l}\text { Magn. } \\
R\end{array}$ & $\begin{array}{l}\text { Magn. } \\
R \\
2 \text { sat } \\
(18)\end{array}$ & $\begin{array}{l}\text { Magn. } \\
V\end{array}$ & $\begin{array}{l}\text { Magn. } \\
\text { no alb. } \\
\text { (20) }\end{array}$ & $\begin{array}{l}\text { Impact } \\
\text { param. } \\
\left({ }^{\prime \prime}\right) \\
(21)\end{array}$ \\
\hline 20071225 & $2 \mathrm{EC} 1 \mathrm{P}$ & 101932 & 105017 & 3591 & 1.4 & 0.917 & 2.697 & 1.024 & 2.697 & 2.697 & 0.005 \\
\hline 20071225 & $2 \mathrm{EC} 1 \mathrm{P}$ & 1765. & 172929 . & 2673 & 5.2 & 0.820 & 1.862 & 0.858 & 1.862 & 1.862 & 0.011 \\
\hline 20071228 & 3 EC 2 P & 54343 . & 54731 . & 248 & 8.8 & 0.066 & 0.074 & 0.022 & 0.074 & 0.074 & 0.083 \\
\hline 20071230 & 1 EC $2 \mathrm{P}$ & 232560 . & 233025 . & 456 & 6.3 & 0.132 & 0.154 & 0.049 & 0.154 & 0.154 & 0.061 \\
\hline 200814 & 1 EC 5 P & 161535 . & 161742 . & 218 & 3.7 & 0.554 & 0.876 & 0.077 & 0.876 & 0.876 & 0.037 \\
\hline 200816 & 3 EC 2 P & 23311 . & 31941. & 5478 & 6.9 & 0.186 & 0.224 & 0.063 & 0.224 & 0.224 & 0.071 \\
\hline 200816 & 3 EC 2 P & 5733. & 62753. & 6062 & 5.5 & 0.175 & 0.209 & 0.059 & 0.209 & 0.209 & 0.072 \\
\hline 200816 & 1 OC $5 \mathrm{~T}$ & 152711. & 15295. & 228 & 3.6 & 0.130 & 0.152 & 0.152 & 0.160 & 0.171 & 0.001 \\
\hline 200819 & $1 \mathrm{OC} 5 \mathrm{~T}$ & 72719. & 72829 . & 140 & 1.3 & 0.130 & 0.152 & 0.152 & 0.160 & 0.171 & 0.002 \\
\hline 2008123 & $5 \mathrm{OC} 1 \mathrm{P}$ & 0247. & 0524 . & 315 & 3.9 & 0.099 & 0.113 & 0.113 & 0.105 & 0.063 & 0.040 \\
\hline 2008124 & $1 \mathrm{OC} 5 \mathrm{~T}$ & 155736 . & 155842 . & 132 & 0.8 & 0.130 & 0.152 & 0.152 & 0.160 & 0.171 & 0.002 \\
\hline 2008127 & $2 \mathrm{OC} 5 \mathrm{~T}$ & 123448 . & 12362. & 147 & 0.2 & 0.129 & 0.150 & 0.150 & 0.158 & 0.169 & 0.003 \\
\hline 2008129 & 5 OC $2 \mathrm{~A}$ & 15042 & 15156. & 149 & 0.6 & 0.126 & 0.146 & 0.146 & 0.149 & 0.169 & 0.008 \\
\hline 2008131 & 2 OC $5 \mathrm{P}$ & 172246 . & 172356 . & 139 & 1.0 & 0.127 & 0.148 & 0.148 & 0.156 & 0.167 & 0.024 \\
\hline 200822 & 5 OC $2 \mathrm{P}$ & 194756. & 19491 & 131 & 1.4 & 0.096 & 0.109 & 0.109 & 0.112 & 0.126 & 0.031 \\
\hline 200824 & $2 \mathrm{OC} 5 \mathrm{P}$ & 22811 & 22911. & 119 & 1.8 & 0.064 & 0.072 & 0.072 & 0.075 & 0.081 & 0.038 \\
\hline 200827 & 5 OC $2 \mathrm{P}$ & 03158. & 0333 . & 129 & 2.2 & 0.069 & 0.077 & 0.077 & 0.079 & 0.089 & 0.036 \\
\hline 200828 & $1 \mathrm{EC} 5 \mathrm{~T}$ & 23296 . & 233212 . & 342 & 3.9 & 1.000 & $* * * * *$ & 0.144 & $* * * * *$ & $* * * * *$ & 0.008 \\
\hline 200829 & $2 \mathrm{OC} 5 \mathrm{P}$ & 24950 . & 2516. & 151 & 2.6 & 0.100 & 0.114 & 0.114 & 0.121 & 0.129 & 0.030 \\
\hline 2008211 & 5 OC $2 \mathrm{~A}$ & 5105. & 51139 . & 188 & 2.9 & 0.126 & 0.146 & 0.146 & 0.149 & 0.169 & 0.016 \\
\hline 2008213 & $2 \mathrm{OC} 5 \mathrm{~T}$ & 72414. & 72560. & 212 & 3.2 & 0.129 & 0.150 & 0.150 & 0.158 & 0.169 & 0.002 \\
\hline 2008215 & $2 \mathrm{OC} 3 \mathrm{~A}$ & 10183. & 105816. & 5263 & 4.3 & 0.329 & 0.434 & 0.434 & 0.442 & 0.476 & 0.011 \\
\hline 2008215 & $2 \mathrm{OC} 3 \mathrm{~A}$ & 17352. & 181417. & 4503 & 7.6 & 0.329 & 0.434 & 0.434 & 0.442 & 0.476 & $0.010 *$ \\
\hline 2008218 & $1 \mathrm{OC} 2 \mathrm{P}$ & 234127. & 234320 . & 226 & 2.8 & 0.134 & 0.157 & 0.157 & 0.167 & 0.246 & 0.037 \\
\hline 2008219 & $3 \mathrm{OC} 1 \mathrm{~T}$ & 175321. & 175617 . & 353 & 3.7 & 0.427 & 0.605 & 0.605 & 0.590 & 0.470 & 0.004 \\
\hline 2008220 & $2 \mathrm{OC} 1 \mathrm{P}$ & 2146 & 213011 . & 3516 & 5.0 & 0.636 & 1.097 & 1.097 & 1.043 & 0.702 & 0.003 \\
\hline 2008221 & $2 \mathrm{OC} 1 \mathrm{P}$ & 193510. & 194444. & 1132 & 6.1 & 0.654 & 1.152 & 1.152 & 1.094 & 0.731 & 0.001 \\
\hline 2008221 & $2 \mathrm{OC} 1 \mathrm{P}$ & 2921. & 24844 & 4355 & 2.0 & 0.642 & 1.114 & 1.114 & 1.059 & 0.711 & 0.002 \\
\hline 2008223 & $4 \mathrm{OC} 2 \mathrm{P}$ & 202422 . & 20272 . & 319 & 5.6 & 0.075 & 0.085 & 0.085 & 0.091 & 0.143 & 0.056 \\
\hline 2008315 & 1 OC $5 \mathrm{P}$ & 62520 & 62826. & 372 & 3.9 & 0.103 & 0.118 & 0.118 & 0.124 & 0.132 & 0.030 \\
\hline 2008413 & $5 \mathrm{EC} 1 \mathrm{~A}$ & 55959. & 6354. & 433 & 4.0 & 0.164 & 0.194 & 0.168 & 0.194 & 0.194 & 0.014 \\
\hline 2008423 & 2 EC 5 P & 185652. & 19234 . & 584 & 3.8 & 0.712 & 1.350 & 0.185 & 1.350 & 1.350 & 0.033 \\
\hline
\end{tabular}

Table 12. Mutual events of the 2006-2008 period: main events predicted with LA06 (6/6).

\begin{tabular}{|c|c|c|c|c|c|c|c|c|c|c|c|}
\hline $\begin{array}{l}\text { Date (TT) } \\
\text { of maximum } \\
\text { year mth day } \\
\text { Cols. }\left(\begin{array}{lll}1 & 2 & 3\end{array}\right)\end{array}$ & $(4567)$ & $\begin{array}{l}\text { Begins } \\
\text { at } \\
\mathrm{h} \mathrm{m} \mathrm{s} \\
\left(\begin{array}{lll}8 & 9 & 10\end{array}\right)\end{array}$ & $\begin{array}{l}\text { h m s } \\
\left(\begin{array}{lll}11 & 12\end{array}\right)\end{array}$ & $\begin{array}{l}\text { Dur. } \\
\text { s } \\
(14)\end{array}$ & $\begin{array}{l}\text { (UR) } \\
(15)\end{array}$ & $\begin{array}{l}\text { Flux } \\
R \\
(16)\end{array}$ & $\begin{array}{l}\text { Magn. } \\
R \\
(17)\end{array}$ & $\begin{array}{l}\text { Magn. } \\
R \\
2 \text { sat } \\
(18)\end{array}$ & $\begin{array}{l}\text { Magn. } \\
V\end{array}$ & $\begin{array}{l}\text { Magn. } \\
\text { no alb. } \\
\text { (20) }\end{array}$ & $\begin{array}{l}\text { Impact } \\
\text { param. } \\
\left({ }^{\prime \prime}\right) \\
(21)\end{array}$ \\
\hline 200857 & $3 \mathrm{EC} 5 \mathrm{P}$ & 132446 & 132959. & 465 & 0.8 & 0.483 & 0.716 & 0.059 & 0.716 & 0.716 & 0.053 \\
\hline 20085 & 5 EC $3 \mathrm{P}$ & 152140 . & 152749 . & 585 & 1.6 & 0.064 & 0.072 & 0.064 & 0.072 & 0.072 & 0.047 \\
\hline 2008 & 5 EC $1 \mathrm{P}$ & 113718. & 11421 & 512 & 3.9 & 0.111 & 0.128 & 0.111 & 0.128 & 0.128 & 0.034 \\
\hline 2008812 & $1 \mathrm{EC} 5 \mathrm{~T}$ & 22158 & 222758 & 1472 & 3.2 & 1.000 & $* * * * *$ & 0.144 & $* * * * *$ & $* * * * *$ & 0.010 \\
\hline 2008819 & 5 EC $2 \mathrm{~A}$ & 9421. & 91635 . & 1334 & 1.8 & 0.161 & 0.191 & 0.146 & 0.191 & 0.191 & 0.020 \\
\hline 2008823 & 5 OC $2 \mathrm{~A}$ & 21652. & 211638 . & 1215 & 1.7 & 0.126 & 0.146 & 0.146 & 0.149 & 0.169 & 0.024 \\
\hline 20081030 & 5 OC $4 \mathrm{~A}$ & 155615 . & 1612. & 575 & 0.3 & 0.103 & 0.118 & 0.118 & 0.104 & 0.103 & 0.021 \\
\hline 20081213 & 5 OC $1 \mathrm{~A}$ & 31117. & 31623 . & 611 & 3.8 & 0.256 & 0.322 & 0.322 & 0.298 & 0.171 & $0.020 *$ \\
\hline 20081219 & 2 EC 5 P & 165336 . & 165957. & 637 & 0.8 & 0.331 & 0.436 & 0.082 & 0.436 & 0.436 & 0.043 \\
\hline 20081223 & 5 OC $4 \mathrm{~A}$ & 6132. & 6187. & 611 & 0.5 & 0.103 & 0.118 & 0.118 & 0.104 & 0.103 & 0.010 \\
\hline 2009111 & 1 OC $5 \mathrm{P}$ & 3322 . & 3748. & 533 & 3.7 & 0.064 & 0.072 & 0.072 & 0.075 & 0.080 & 0.038 \\
\hline 2009111 & $1 \mathrm{OC} 5 \mathrm{~T}$ & 163117. & 163743 . & 764 & 3.7 & 0.130 & 0.152 & 0.152 & 0.160 & 0.171 & 0.001 \\
\hline 2009611 & $1 \mathrm{EC} 5 \mathrm{~T}$ & 183936 . & 1918. & 2477 & 2.2 & 1.000 & $* * * * *$ & 0.144 & $* * * * *$ & $* * * * *$ & 0.014 \\
\hline 2009122 & $1 \mathrm{EC} 5 \mathrm{~T}$ & 82728 & 8536. & 2962 & 1.9 & 1.000 & $* * * * *$ & 0.144 & $* * * * *$ & $* * * * *$ & 0.002 \\
\hline
\end{tabular}


Table 13. Mutual events of the 2006-2008 period: main events predicted with GUST86 (1/6).

\begin{tabular}{|c|c|c|c|c|c|c|c|c|c|c|c|}
\hline $\begin{array}{l}\text { Date (TT) } \\
\text { of maximum } \\
\text { year mth day } \\
\text { Cols. }\left(\begin{array}{llll}1 & 2 & 3\end{array}\right)\end{array}$ & $\begin{array}{l}\text { Event } \\
\text { (4 } 5667 \text { ) }\end{array}$ & 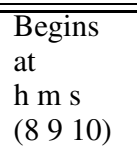 & 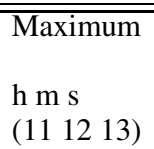 & $\begin{array}{l}\text { Dur. } \\
\text { s } \\
\text { (14) }\end{array}$ & $\begin{array}{l}\text { Dist. } \\
\text { (UR) } \\
\text { (15) }\end{array}$ & $\begin{array}{l}\text { flux } \\
R \\
(16)\end{array}$ & $\begin{array}{l}\text { Magn. } \\
R \\
(17)\end{array}$ & $\begin{array}{l}\text { Magn. } \\
R \\
2 \text { sat } \\
(18)\end{array}$ & $\begin{array}{l}\text { Magn. } \\
V \\
(19)\end{array}$ & $\begin{array}{l}\text { Magn. } \\
\text { no alb. } \\
\text { (20) }\end{array}$ & $\begin{array}{l}\text { Impact } \\
\text { param. } \\
\left({ }^{\prime \prime}\right) \\
(21)\end{array}$ \\
\hline 200655 & $5 \mathrm{OC} 1 \mathrm{P}$ & 102438 . & 102619 & 202 & 3.9 & 0.014 & 0.016 & 0.016 & 0.015 & 0.009 & 0.051 \\
\hline 2006511 & 1 OC $5 \mathrm{c}$ & & 173610 . & & 3.9 & & & & & & 0.1 \\
\hline 200663 & $1 \mathrm{OC} 5 \mathrm{P}$ & 1033. & 10744 . & 562 & 3.8 & 0.128 & 0.149 & 0.149 & 0.157 & 0.168 & 0.025 \\
\hline 2006616 & $1 \mathrm{OC} 5 \mathrm{~T}$ & 03655. & 03912 . & 273 & 3.8 & 0.130 & 0.152 & 0.152 & 0.160 & 0.171 & 0.001 \\
\hline 2006622 & $5 \mathrm{OC} 1 \mathrm{c}$ & & 82056. & & 3.4 & & & & & & 0.1 \\
\hline 200672 & 5 OC $1 \mathrm{~A}$ & 9400. & 94550 . & 700 & 3.7 & 0.256 & 0.322 & 0.322 & 0.298 & 0.171 & 0.004 \\
\hline 200678 & $1 \mathrm{OC} 5 \mathrm{~T}$ & 163733 . & 164039. & 372 & 4.0 & 0.130 & 0.152 & 0.152 & 0.160 & 0.171 & 0.001 \\
\hline 2006715 & $5 \mathrm{OC} 1 \mathrm{P}$ & 083 & 0815 & 24 & 3.8 & 0.000 & 0.000 & 0.000 & 0.000 & 0.000 & 0.058 \\
\hline 2007310 & $1 \mathrm{OC} 5 \mathrm{P}$ & 4327. & 43354 . & 214 & 3.8 & 0.075 & 0.084 & 0.084 & 0.089 & 0.094 & 0.035 \\
\hline 2007316 & $5 \mathrm{OC} 1 \mathrm{~A}$ & 12134. & 121450 . & 213 & 3.5 & 0.257 & 0.322 & 0.322 & 0.298 & 0.171 & 0.021 \\
\hline 2007325 & $1 \mathrm{OC} 5 \mathrm{P}$ & 121746 . & 121825 . & 78 & 0.6 & 0.027 & 0.030 & 0.030 & 0.031 & 0.033 & 0.045 \\
\hline 2007326 & $5 \mathrm{OC} 1 \mathrm{P}$ & 135339 . & 135920. & 681 & 3.6 & 0.167 & 0.198 & 0.198 & 0.185 & 0.108 & 0.033 \\
\hline 200741 & $1 \mathrm{EC} 5 \mathrm{P}$ & 203837. & 20412 & 231 & 4.0 & 0.186 & 0.224 & 0.025 & 0.224 & 0.224 & 0.047 \\
\hline 200748 & $5 \mathrm{EC} 1 \mathrm{P}$ & 435 . & 4539 & 278 & 3.8 & 0.148 & 0.174 & 0.151 & 0.174 & 0.174 & 0.027 \\
\hline 2007414 & $1 \mathrm{EC} 5 \mathrm{P}$ & 114558 . & 11487. & 227 & 3.6 & 0.813 & 1.822 & 0.115 & 1.822 & 1.822 & 0.030 \\
\hline 2007420 & $5 \mathrm{EC} 1 \mathrm{P}$ & 193331 . & 19355. & 150 & 3.1 & 0.055 & 0.061 & 0.053 & 0.061 & 0.061 & 0.043 \\
\hline 2007422 & $1 \mathrm{OC} 5 \mathrm{P}$ & 123724 . & 123815 . & 102 & 2.6 & 0.033 & 0.036 & 0.036 & 0.038 & 0.040 & 0.044 \\
\hline 2007424 & $2 \mathrm{OC} 1 \mathrm{P}$ & 6204 & 62539 & 671 & 6.2 & 0.131 & 0.152 & 0.152 & 0.147 & 0.112 & 0.054 \\
\hline 2007427 & 1 EC 5 & 32745 . & 32831 . & & 2.8 & 0.006 & 0.006 & 0.001 & 0.006 & 0.006 & 0.058 \\
\hline 2007428 & $5 \mathrm{OC} 1 \mathrm{P}$ & 203046 . & 203116 . & 61 & 3.0 & 0.010 & 0.010 & 0.010 & 0.010 & 0.006 & 0.052 \\
\hline 2007430 & $1 \mathrm{OC} 2 \mathrm{P}$ & 112120. & 112628 & 617 & 6.2 & 0.259 & 0.325 & 0.325 & 0.348 & 0.537 & 0.013 \\
\hline 2007430 & 3 OC $2 P$ & 43751. & 44244 . & 585 & 8.5 & 0.201 & 0.244 & 0.244 & 0.263 & 0.440 & 0.020 \\
\hline 2007430 & $5 \mathrm{EC} 1 \mathrm{~A}$ & 201022 . & 201412 . & 429 & 3.9 & 0.164 & 0.194 & 0.168 & 0.194 & 0.194 & 0.018 \\
\hline 200753 & $1 \mathrm{OC} 3 \mathrm{P}$ & 21258 & 2223. & 1108 & 6.1 & 0.274 & 0.348 & 0.348 & 0.354 & 0.379 & 0.027 \\
\hline 200753 & $1 \mathrm{OC} 3 \mathrm{P}$ & 125718. & 13945 . & 1493 & 1.0 & 0.218 & 0.267 & 0.267 & 0.272 & 0.290 & 0.037 \\
\hline 200753 & $2 \mathrm{OC} 1 \mathrm{P}$ & 91159. & 9142. & 246 & 3.6 & 0.294 & 0.378 & 0.378 & 0.365 & 0.270 & 0.035 \\
\hline 200753 & $2 \mathrm{OC} 3 \mathrm{~A}$ & 83248 . & 83545 . & 353 & 3.2 & 0.329 & 0.434 & 0.434 & 0.442 & 0.476 & 0.000 \\
\hline 200753 & $4 \mathrm{OC} 1 \mathrm{P}$ & 213453 . & 213728 . & 309 & 3.1 & 0.246 & 0.307 & 0.307 & 0.300 & 0.243 & 0.043 \\
\hline 200753 & $4 \mathrm{OC} 3 \mathrm{~A}$ & 233654 . & 234045 . & 463 & 2.3 & 0.409 & 0.570 & 0.570 & 0.591 & 0.714 & 0.000 \\
\hline 200754 & $1 \mathrm{OC} 3 \mathrm{P}$ & 8222 . & 8739. & 634 & 6.3 & 0.214 & 0.261 & 0.261 & 0.266 & 0.284 & 0.038 \\
\hline 200754 & $4 \mathrm{OC} 2 \mathrm{P}$ & 19531. & 19836. & 370 & 4.1 & 0.201 & 0.244 & 0.244 & 0.263 & 0.435 & 0.021 \\
\hline 200755 & $1 \mathrm{OC} 2 \mathrm{P}$ & 03448 . & 03643 . & 230 & 0.8 & 0.244 & 0.304 & 0.304 & 0.325 & 0.498 & 0.016 \\
\hline 200756 & $2 \mathrm{OC} 1 \mathrm{P}$ & 17129 & 17451. & 403 & 6.1 & 0.203 & 0.246 & 0.246 & 0.238 & 0.179 & 0.045 \\
\hline 200757 & $1 \mathrm{EC} 5 \mathrm{P}$ & 33557. & 33843 . & 302 & 3.9 & 0.975 & 4.017 & 0.140 & 4.017 & 4.017 & 0.023 \\
\hline 2007511 & $5 \mathrm{OC} 4 \mathrm{c}$ & & 114534. & & 3.8 & & & & & & 0.1 \\
\hline 2007529 & $1 \mathrm{EC} 5 \mathrm{~T}$ & 194618. & 195035 . & 481 & 3.9 & 1.000 & $* * * * *$ & 0.144 & $* * * * *$ & $* * * * *$ & 0.005 \\
\hline
\end{tabular}


J.-E. Arlot et al.: Mutual events of the Uranian satellites, Online Material $p 8$

Table 14. Mutual events of the 2006-2008 period: main events predicted with GUST86 (2/6).

\begin{tabular}{|c|c|c|c|c|c|c|c|c|c|c|c|}
\hline $\begin{array}{l}\text { Date (TT) } \\
\text { of maximum } \\
\text { year mth day } \\
\text { Cols. }\left(\begin{array}{lll}1 & 2 & 3\end{array}\right)\end{array}$ & $(4567)$ & $\begin{array}{l}\text { Begins } \\
\text { at } \\
\mathrm{h} \mathrm{m} \mathrm{s} \\
\left(\begin{array}{lll}8 & 9 & 10\end{array}\right)\end{array}$ & $\begin{array}{l}\mathrm{h} \mathrm{m} \mathrm{s} \\
\left(\begin{array}{lll}11 & 12 & 13\end{array}\right)\end{array}$ & $\begin{array}{l}\text { Dur. } \\
\text { s } \\
\text { (14) }\end{array}$ & $\begin{array}{l}\text { (UR) } \\
(15)\end{array}$ & $\begin{array}{l}\text { Flux } \\
R\end{array}$ & $\begin{array}{l}\text { Magn. } \\
R \\
(17)\end{array}$ & $\begin{array}{l}\text { Magn. } \\
R \\
2 \text { sat } \\
(18)\end{array}$ & $\begin{array}{l}\text { Magn. } \\
V\end{array}$ & $\begin{array}{l}\text { Magn. } \\
\text { no alb. } \\
\text { (20) }\end{array}$ & $\begin{array}{l}\text { Impact } \\
\text { param. } \\
\left({ }^{\prime \prime}\right) \\
(21)\end{array}$ \\
\hline 200761 & $1 \mathrm{EC} 5 \mathrm{P}$ & 104940. & 10513 & 139 & 2.4 & 0.944 & 3.125 & 0.135 & 3.125 & 3.125 & 0.023 \\
\hline 200767 & $5 \mathrm{EC} 1 \mathrm{~A}$ & 18453. & 184626 . & 140 & 1.8 & 0.163 & 0.194 & 0.168 & 0.194 & 0.194 & 0.011 \\
\hline 2007614 & $1 \mathrm{EC} 5 \mathrm{~T}$ & 24323 . & 24443 . & 136 & 1.4 & 1.000 & $* * * * *$ & 0.144 & $* * * * *$ & $* * * * *$ & 0.003 \\
\hline 2007620 & $5 \mathrm{EC} 1 \mathrm{~A}$ & 10418. & 104224 . & 127 & 0.7 & 0.164 & 0.195 & 0.169 & 0.195 & 0.195 & 0.011 \\
\hline 2007626 & 1 EC 5 P & 184050. & 18421 & 115 & 0.3 & 0.973 & 3.902 & 0.139 & 3.902 & 3.902 & 0.020 \\
\hline 2007627 & $5 \mathrm{EC} 1 \mathrm{~A}$ & 191938. & 192351 . & 471 & 3.9 & 0.163 & 0.194 & 0.168 & 0.194 & 0.194 & 0.023 \\
\hline 2007629 & 2 EC 5 P & 19520. & 19723. & 200 & 3.5 & 0.670 & 1.203 & 0.173 & 1.203 & 1.203 & 0.033 \\
\hline 200771 & 5 EC 2 P & 211733. & 211929 . & 191 & 3.0 & 0.129 & 0.150 & 0.115 & 0.150 & 0.150 & 0.030 \\
\hline 200773 & 2 EC 5 P & 23371. & 233838 . & 156 & 2.8 & 0.950 & 3.256 & 0.255 & 3.256 & 3.256 & 0.021 \\
\hline 200776 & 5 EC 2 A & 15415. & 15541. & 131 & 2.3 & 0.135 & 0.158 & 0.121 & 0.158 & 0.158 & 0.029 \\
\hline 200778 & 2 EC 5 P & 41633. & 41756. & 127 & 2.1 & 0.843 & 2.008 & 0.223 & 2.008 & 2.008 & 0.027 \\
\hline 2007710 & 5 EC $2 \mathrm{P}$ & 63710. & 63816. & 126 & 1.6 & 0.068 & 0.076 & 0.059 & 0.076 & 0.076 & 0.041 \\
\hline 2007712 & 2 EC 5 P & 9030. & 9129. & 107 & 1.3 & 0.269 & 0.341 & 0.066 & 0.341 & 0.341 & 0.045 \\
\hline 2007712 & 5 OC $3 \mathrm{~A}$ & 34511. & 35221 . & 860 & 1.3 & 0.099 & 0.113 & 0.113 & 0.111 & 0.096 & 0.012 \\
\hline 2007714 & $5 \mathrm{EC} 2 \mathrm{c}$ & & 11246. & & 0.8 & & & & & & 0.1 \\
\hline 2007716 & $2 \mathrm{EC} 5 \mathrm{c}$ & & 134754 . & & 0.5 & & & & & & 0.1 \\
\hline 2007722 & $1 \mathrm{EC} 5 \mathrm{c}$ & & 2405. & & 0.2 & & & & & & 0.1 \\
\hline 2007726 & 1 EC $5 \mathrm{P}$ & 185830. & 19241 . & 457 & 3.9 & 0.718 & 1.374 & 0.101 & 1.374 & 1.374 & 0.033 \\
\hline 2007730 & 5 OC $4 \mathrm{P}$ & 11116. & 11174 . & 715 & 2.5 & 0.044 & 0.049 & 0.049 & 0.043 & 0.043 & 0.055 \\
\hline 200785 & 4 OC 2 P & 134256 . & 135220 . & 1159 & 8.5 & 0.022 & 0.025 & 0.025 & 0.026 & 0.041 & $0.08 *$ \\
\hline 200786 & $1 \mathrm{OC} 5 \mathrm{P}$ & 103441 . & 103624 . & 205 & 3.6 & 0.108 & 0.124 & 0.124 & 0.131 & 0.139 & 0.031 \\
\hline 200786 & 4 OC $2 \mathrm{P}$ & 05635. & 11139. & 1807 & 3.9 & 0.049 & 0.054 & 0.054 & 0.058 & 0.091 & $0.07 *$ \\
\hline 2007813 & $1 \mathrm{OC} 2 \mathrm{P}$ & 305. & 3515. & 620 & 6.3 & 0.235 & 0.291 & 0.291 & 0.311 & 0.475 & 0.019 \\
\hline 2007813 & $1 \mathrm{OC} 4 \mathrm{P}$ & 132124 . & 13244. & 321 & 2.0 & 0.301 & 0.389 & 0.389 & 0.350 & 0.440 & 0.022 \\
\hline 2007814 & $2 \mathrm{OC} 1 \mathrm{P}$ & 20922 . & 201120 . & 235 & 1.6 & 0.483 & 0.717 & 0.717 & 0.688 & 0.488 & 0.018 \\
\hline 2007814 & $2 \mathrm{OC} 4 \mathrm{P}$ & 1294. & 13232. & 417 & 7.1 & 0.193 & 0.233 & 0.233 & 0.211 & 0.262 & 0.044 \\
\hline 2007814 & 2 OC $5 \mathrm{~T}$ & 225529 . & 225715 . & 212 & 3.3 & 0.129 & 0.150 & 0.150 & 0.158 & 0.169 & 0.002 \\
\hline 2007815 & 2 OC $3 \mathrm{~A}$ & 91048. & 91510. & 523 & 8.0 & 0.329 & 0.434 & 0.434 & 0.442 & 0.476 & 0.004 \\
\hline 2007816 & $1 \mathrm{OC} 2 \mathrm{P}$ & 112824 . & 113030 . & 252 & 2.9 & 0.222 & 0.273 & 0.273 & 0.291 & 0.442 & 0.022 \\
\hline 2007819 & $2 \mathrm{OC} 1 \mathrm{P}$ & 75321. & 75832. & 622 & 6.2 & 0.085 & 0.097 & 0.097 & 0.094 & 0.072 & 0.065 \\
\hline 2007820 & 5 OC $2 \mathrm{P}$ & 134827 . & 13546. & 692 & 3.5 & 0.054 & 0.061 & 0.061 & 0.062 & 0.070 & 0.043 \\
\hline
\end{tabular}


Table 15. Mutual events of the 2006-2008 period: main events predicted with GUST86 (3/6).

\begin{tabular}{|c|c|c|c|c|c|c|c|c|c|c|c|}
\hline $\begin{array}{l}\text { Date (TT) } \\
\text { of maximum } \\
\text { year mth day } \\
\text { Cols. }\left(\begin{array}{llll}1 & 2 & 3\end{array}\right)\end{array}$ & $\begin{array}{l}\text { Event } \\
\text { (4 } 5567 \text { ) }\end{array}$ & $\begin{array}{l}\text { Begins } \\
\text { at } \\
\mathrm{h} \mathrm{m} \mathrm{s} \\
\left(\begin{array}{lll}8 & 9 & 10\end{array}\right)\end{array}$ & 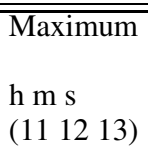 & $\begin{array}{l}\text { Dur. } \\
\text { s } \\
\text { (14) }\end{array}$ & $\begin{array}{l}\text { Dist. } \\
\text { (UR) } \\
\text { (15) }\end{array}$ & $\begin{array}{l}\text { Flux } \\
R \\
(16)\end{array}$ & $\begin{array}{l}\text { Magn. } \\
R \\
(17)\end{array}$ & $\begin{array}{l}\text { Magn. } \\
R \\
2 \text { sat } \\
(18)\end{array}$ & $\begin{array}{l}\text { Magn. } \\
V \\
(19)\end{array}$ & $\begin{array}{l}\text { Magn. } \\
\text { no alb. } \\
\text { (20) }\end{array}$ & $\begin{array}{l}\text { Impact } \\
\text { param. } \\
\left({ }^{\prime \prime}\right) \\
(21)\end{array}$ \\
\hline 2007822 & $2 \mathrm{EC} 5 \mathrm{~T}$ & 14586 & 15215 & 440 & 3.9 & 1.000 & $* * * * *$ & 0.270 & $* * * * *$ & $* * * * *$ & 0.016 \\
\hline 2007824 & $1 \mathrm{OC} 2 \mathrm{P}$ & 121445 . & 122151 . & 852 & 6.1 & 0.109 & 0.126 & 0.126 & 0.133 & 0.195 & 0.047 \\
\hline 2007824 & 5 EC $3 \mathrm{~A}$ & 134055. & 134330 . & 227 & 2.7 & 0.096 & 0.110 & 0.097 & 0.110 & 0.110 & 0.026 \\
\hline 2007825 & $1 \mathrm{OC} 2 \mathrm{P}$ & 7145 . & 75456. & 9944 & 3.2 & 0.033 & 0.036 & 0.036 & 0.039 & 0.055 & $0.07 *$ \\
\hline 200791 & $5 \mathrm{EC} 1 \mathrm{~A}$ & 1869. & 18727. & 132 & 1.2 & 0.164 & 0.194 & 0.168 & 0.194 & 0.194 & 0.009 \\
\hline 200796 & $3 \mathrm{EC} 5 \mathrm{~T}$ & 20257 . & 202659 . & 173 & 0.1 & 1.000 & $* * * * *$ & 0.126 & $* * * * *$ & $* * * * *$ & 0.012 \\
\hline 200798 & $1 \mathrm{EC} 5 \mathrm{~T}$ & 250 . & 2619 & 133 & 1.7 & 1.000 & $* * * * *$ & 0.144 & $* * * * *$ & $* * * * *$ & 0.017 \\
\hline 2007914 & $5 \mathrm{EC} 1 \mathrm{p}$ & 10239. & 10335 . & & 2.3 & 0.006 & 0.006 & 0.006 & 0.006 & 0.006 & 0.055 \\
\hline 2007922 & $1 \mathrm{EC} 5 \mathrm{P}$ & 182051. & 18267. & 587 & 3.8 & 0.839 & 1.983 & 0.119 & 1.983 & 1.983 & 0.029 \\
\hline 2007929 & $5 \mathrm{OC} 1 \mathrm{P}$ & 11934. & 1224 & 300 & 3.9 & 0.185 & 0.222 & 0.222 & 0.206 & 0.121 & 0.035 \\
\hline 2007107 & 2 EC $5 \mathrm{P}$ & 18020. & 18145 . & 133 & 2.1 & 0.888 & 2.377 & 0.236 & 2.377 & 2.377 & 0.025 \\
\hline 2007108 & $1 \mathrm{OC} 5 \mathrm{P}$ & 04320 . & 04428 . & 136 & 1.7 & 0.127 & 0.147 & 0.147 & 0.155 & 0.166 & $0.03 *$ \\
\hline 2007109 & $5 \mathrm{EC} 2 \mathrm{c}$ & & 20246 & & 2.5 & & & & & & 0.1 \\
\hline 20071011 & $5 \mathrm{OC} 1 \mathrm{~A}$ & 163612 . & 16386. & 228 & 3.5 & 0.257 & 0.322 & 0.322 & 0.298 & 0.171 & 0.003 \\
\hline 20071012 & 3 EC $5 \mathrm{P}$ & 0055. & 0246 . & 129 & 1.9 & 0.365 & 0.492 & 0.044 & 0.492 & 0.492 & 0.056 \\
\hline 20071012 & $4 \mathrm{EC} 5 \mathrm{~T}$ & 94717. & 9510. & 344 & 3.6 & 1.000 & $* * * * *$ & 0.137 & $* * * * *$ & $* * * * *$ & 0.006 \\
\hline 20071018 & $1 \mathrm{OC} 5 \mathrm{c}$ & & 02944 . & & 3.1 & & & & & & 0.1 \\
\hline 20071021 & $1 \mathrm{EC} 2 \mathrm{P}$ & 22535 . & 231132 . & 2087 & 0.5 & 0.199 & 0.241 & 0.075 & 0.241 & 0.241 & 0.055 \\
\hline $2007 \quad 1021$ & $5 \mathrm{EC} 1 \mathrm{~A}$ & 18529 . & 18128 & 756 & 3.7 & 0.165 & 0.196 & 0.169 & 0.196 & 0.196 & 0.014 \\
\hline 20071026 & $1 \mathrm{EC} 5 \mathrm{P}$ & 12550 & 12740 & 190 & 3.1 & 0.766 & 1.579 & 0.108 & 1.579 & 1.579 & 0.031 \\
\hline 2007112 & $5 \mathrm{EC} 3 \mathrm{~A}$ & 202937. & 203160 . & 203 & 2.8 & 0.070 & 0.079 & 0.070 & 0.079 & 0.079 & 0.045 \\
\hline 20071111 & $1 \mathrm{EC} 3 \mathrm{P}$ & 3153. & 31330. & 1237 & 0.6 & 0.234 & 0.289 & 0.145 & 0.289 & 0.289 & 0.052 \\
\hline 20071119 & $1 \mathrm{EC} 5 \mathrm{~T}$ & 1803. & 1881 & 903 & 3.6 & 1.000 & $* * * * *$ & 0.144 & $* * * * *$ & $* * * * *$ & 0.017 \\
\hline 20071121 & $2 \mathrm{EC} 1 \mathrm{P}$ & 164453 . & 164719 & 217 & 5.2 & 0.100 & 0.114 & 0.075 & 0.114 & 0.114 & 0.064 \\
\hline 20071123 & 4 EC $2 p$ & 5576. & 55938. & & 9.1 & 0.005 & 0.005 & 0.002 & 0.005 & 0.005 & 0.096 \\
\hline 20071124 & $1 \mathrm{EC} 2 \mathrm{c}$ & & 153611 & & 5.3 & & & & & & 0.1 \\
\hline 20071127 & $1 \mathrm{EC} 2 \mathrm{P}$ & 225029 . & 225311. & 274 & 4.8 & 0.280 & 0.356 & 0.107 & 0.356 & 0.356 & 0.047 \\
\hline 20071128 & $1 \mathrm{EC} 3 \mathrm{P}$ & 13555 . & 14028 & 466 & 5.9 & 0.346 & 0.462 & 0.223 & 0.462 & 0.462 & 0.038 \\
\hline 20071129 & $2 \mathrm{EC} 3 \mathrm{~A}$ & 124130 . & 124811. & 691 & 8.9 & 0.526 & 0.810 & 0.496 & 0.810 & 0.810 & 0.003 \\
\hline 20071129 & $2 \mathrm{EC} 4 \mathrm{p}$ & 1929. & 19457. & & 7.3 & 0.026 & 0.029 & 0.019 & 0.029 & 0.029 & 0.088 \\
\hline 20071130 & $1 \mathrm{EC} 5 \mathrm{~T}$ & 85222. & 85438. & 226 & 3.4 & 1.000 & $* * * * *$ & 0.144 & $* * * * *$ & $* * * * *$ & 0.009 \\
\hline 20071130 & $2 \mathrm{EC} 1 \mathrm{P}$ & 21334 & 213523 & 185 & 5.7 & 0.048 & 0.053 & 0.035 & 0.053 & 0.053 & 0.070 \\
\hline
\end{tabular}


J.-E. Arlot et al.: Mutual events of the Uranian satellites, Online Material p 10

Table 16. Mutual events of the 2006-2008 period: main events predicted with GUST86 (4/6).

\begin{tabular}{|c|c|c|c|c|c|c|c|c|c|c|c|}
\hline $\begin{array}{l}\text { Date (TT) } \\
\text { Of maximum } \\
\text { year mth day } \\
\text { Cols. }\left(\begin{array}{lll}1 & 2 & 3\end{array}\right)\end{array}$ & $(4567)$ & $\begin{array}{l}\text { Begins } \\
\text { at } \\
\mathrm{h} \mathrm{m} \mathrm{s} \\
(89910)\end{array}$ & $\begin{array}{l}\mathrm{h} \mathrm{m} \mathrm{s} \\
(111213)\end{array}$ & $\begin{array}{l}\text { Dur. } \\
\text { s } \\
\text { (14) }\end{array}$ & $\begin{array}{l}\text { (UR) } \\
\text { (15) }\end{array}$ & $\begin{array}{l}\text { Flux } \\
R\end{array}$ & $\begin{array}{l}\text { Magn. } \\
R \\
(17)\end{array}$ & $\begin{array}{l}\text { Magn. } \\
R \\
2 \text { sat } \\
(18)\end{array}$ & $\begin{array}{l}\text { Magn. } \\
V\end{array}$ & $\begin{array}{l}\text { Magn. } \\
\text { no alb. } \\
\text { (20) }\end{array}$ & $\begin{array}{l}\text { Impact } \\
\text { param. } \\
\left({ }^{\prime \prime}\right) \\
(21)\end{array}$ \\
\hline 20071130 & $3 \mathrm{EC} 4 \mathrm{P}$ & 183216 . & 184634 & 1482 & 15.6 & 0.762 & 1.558 & 0.491 & 1.558 & 1.558 & 0.020 \\
\hline 2007122 & 1 EC 2 P & 133718. & 133857. & 114 & 0.2 & 0.065 & 0.073 & 0.024 & 0.073 & 0.073 & 0.068 \\
\hline 2007122 & 3 EC 2 P & 171038. & 171341 . & 265 & 2.3 & 0.356 & 0.478 & 0.124 & 0.478 & 0.478 & 0.057 \\
\hline 2007123 & 3 EC $1 P$ & 12326 & 12728. & 410 & 5.0 & 0.882 & 2.320 & 0.572 & 2.320 & 2.320 & 0.020 \\
\hline 2007124 & 2 EC $1 P$ & 5259. & 5531. & 280 & 4.2 & 0.593 & 0.975 & 0.545 & 0.975 & 0.975 & 0.025 \\
\hline 2007126 & 4 EC $1 P$ & 32033 . & 32323 . & 201 & 3.5 & 0.174 & 0.208 & 0.096 & 0.208 & 0.208 & 0.070 \\
\hline 2007126 & 4 EC 2 P & 55846 . & 628. & 272 & 4.7 & 0.311 & 0.405 & 0.115 & 0.405 & 0.405 & 0.058 \\
\hline 2007126 & 4 EC 3 P & 13504. & 13558. & 475 & 7.9 & 0.636 & 1.097 & 0.438 & 1.097 & 1.097 & 0.023 \\
\hline 2007127 & 1 EC 2 P & 32838 . & 33230 . & 400 & 6.0 & 0.275 & 0.349 & 0.105 & 0.349 & 0.349 & 0.048 \\
\hline 2007127 & 1 EC $3 \mathrm{~A}$ & 13121. & 13411. & 277 & 1.3 & 0.517 & 0.789 & 0.352 & 0.789 & 0.789 & 0.006 \\
\hline 2007128 & 2 EC $1 P$ & 195416. & 195613. & 187 & 0.8 & 0.453 & 0.655 & 0.390 & 0.655 & 0.655 & 0.034 \\
\hline 2007128 & 2 EC $3 \mathrm{P}$ & 15213. & 1564 & 445 & 7.3 & 0.418 & 0.587 & 0.374 & 0.587 & 0.587 & 0.029 \\
\hline 20071210 & $1 \mathrm{EC} 2 \mathrm{~A}$ & 111413. & 111642 . & 257 & 3.7 & 0.832 & 1.936 & 0.353 & 1.936 & 1.936 & 0.001 \\
\hline 20071211 & 3 EC $1 P$ & 13127. & 131441. & 238 & 0.8 & 0.590 & 0.969 & 0.348 & 0.969 & 0.969 & 0.041 \\
\hline 20071211 & 3 EC 2 P & 4422. & 44532 . & 359 & 4.9 & 0.945 & 3.148 & 0.366 & 3.148 & 3.148 & 0.009 \\
\hline 20071212 & $1 \mathrm{EC} 4 \mathrm{~A}$ & 144021 . & 144317 . & 268 & 1.0 & 0.485 & 0.720 & 0.311 & 0.720 & 0.720 & 0.017 \\
\hline 20071212 & $2 \mathrm{EC} 4 \mathrm{~A}$ & 163044. & 16343. & 315 & 1.7 & 0.508 & 0.770 & 0.458 & 0.770 & 0.770 & 0.014 \\
\hline 20071212 & $3 \mathrm{EC} 4 \mathrm{~A}$ & 1310. & 1756. & 416 & 3.3 & 0.721 & 1.387 & 0.459 & 1.387 & 1.387 & 0.003 \\
\hline 20071213 & $2 \mathrm{EC} 1 \mathrm{P}$ & 9422. & 9938. & 580 & 6.2 & 0.528 & 0.815 & 0.470 & 0.815 & 0.815 & 0.030 \\
\hline 20071215 & $1 \mathrm{EC} 2 \mathrm{~A}$ & 21217. & 21427 . & 220 & 1.5 & 0.810 & 1.805 & 0.343 & 1.805 & 1.805 & 0.002 \\
\hline 20071215 & 1 EC $3 \mathrm{P}$ & 14060 . & 14356. & 253 & 4.7 & 0.110 & 0.127 & 0.066 & 0.127 & 0.127 & 0.069 \\
\hline 20071216 & $2 \mathrm{EC} 1 \mathrm{P}$ & 173047. & 173259. & 220 & 3.1 & 0.513 & 0.782 & 0.454 & 0.782 & 0.782 & 0.030 \\
\hline 20071217 & 2 EC $5 \mathrm{~T}$ & 72921. & 73149. & 254 & 3.6 & 1.000 & $* * * * *$ & 0.270 & $* * * * *$ & $* * * * *$ & 0.019 \\
\hline 20071217 & $4 \mathrm{EC} 3 \mathrm{~A}$ & 141056. & 141830 . & 749 & 13.9 & 0.775 & 1.618 & 0.563 & 1.618 & 1.618 & 0.004 \\
\hline 20071219 & $1 \mathrm{EC} 2 \mathrm{P}$ & 141741 . & 142526 & 862 & 6.2 & 0.706 & 1.331 & 0.292 & 1.331 & 1.331 & 0.017 \\
\hline 20071219 & 3 EC $2 P$ & 163750 . & 164137. & 338 & 7.2 & 0.305 & 0.396 & 0.105 & 0.396 & 0.396 & 0.061 \\
\hline 20071221 & $2 \mathrm{EC} 1 \mathrm{P}$ & 82813. & 83019. & 206 & 2.2 & 0.520 & 0.796 & 0.461 & 0.796 & 0.796 & 0.029 \\
\hline 20071224 & $2 \mathrm{EC} 1 \mathrm{P}$ & 184452. & 185354 . & 1010 & 6.1 & 0.362 & 0.489 & 0.300 & 0.489 & 0.489 & 0.042 \\
\hline
\end{tabular}


J.-E. Arlot et al.: Mutual events of the Uranian satellites, Online Material p 11

Table 17. Mutual events of the 2006-2008 period: main events predicted with GUST86 (5/6).

\begin{tabular}{|c|c|c|c|c|c|c|c|c|c|c|c|}
\hline $\begin{array}{l}\text { Date (TT) } \\
\text { of maximum } \\
\text { year mth day } \\
\text { Cols. }\left(\begin{array}{lll}1 & 2 & 3\end{array}\right)\end{array}$ & $\begin{array}{l}\text { Event } \\
(4567)\end{array}$ & 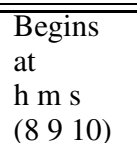 & $\begin{array}{l}\mathrm{h} \mathrm{m} \mathrm{s} \\
(111213)\end{array}$ & $\begin{array}{l}\text { Dur. } \\
\text { s } \\
(14)\end{array}$ & $\begin{array}{l}\text { Dist. } \\
\text { (UR) } \\
\text { (15) }\end{array}$ & $\begin{array}{l}\text { Flux } \\
R \\
(16)\end{array}$ & $\begin{array}{l}\text { Magn. } \\
R \\
(17)\end{array}$ & $\begin{array}{l}\text { Magn. } \\
R \\
2 \text { sat } \\
(18)\end{array}$ & $\begin{array}{l}\text { Magn. } \\
V \\
(19)\end{array}$ & $\begin{array}{l}\text { Magn. } \\
\text { no alb. } \\
\text { (20) }\end{array}$ & $\begin{array}{l}\text { Impact } \\
\text { param. } \\
\left({ }^{\prime \prime}\right) \\
(21)\end{array}$ \\
\hline 20071225 & $2 \mathrm{EC} 1 \mathrm{P}$ & 102620 & 105747 & 3675 & 1.4 & 0.910 & 2.611 & 1.011 & 2.611 & 2.611 & 0.006 \\
\hline 20071225 & $2 \mathrm{EC} 1 \mathrm{P}$ & 1703. & 172414 . & 2764 & 5.2 & 0.814 & 1.827 & 0.848 & 1.827 & 1.827 & 0.011 \\
\hline 20071228 & 3 EC $2 p$ & 5422. & 5455 . & & 8.8 & 0.027 & 0.030 & 0.009 & 0.030 & 0.030 & 0.090 \\
\hline 20071230 & $1 \mathrm{EC} 2 \mathrm{P}$ & 23251 . & 23290. & 395 & 6.3 & 0.086 & 0.098 & 0.032 & 0.098 & 0.098 & 0.065 \\
\hline 200814 & $1 \mathrm{EC} 5 \mathrm{~T}$ & 161521 . & 161750 . & 268 & 3.7 & 1.000 & $* * * * *$ & 0.144 & $* * * * *$ & $* * * * *$ & 0.020 \\
\hline 200816 & 3 EC $2 p$ & 23641 & 336. & & 6.9 & 0.013 & 0.014 & 0.004 & 0.014 & 0.014 & 0.091 \\
\hline 200816 & 3 EC $2 p$ & 61952. & 62753. & & 5.5 & 0.001 & 0.001 & 0.000 & 0.001 & 0.001 & 0.095 \\
\hline 200816 & 1 OC $5 \mathrm{P}$ & 152739. & 15299. & 180 & 3.6 & 0.068 & 0.076 & 0.076 & 0.080 & 0.085 & 0.037 \\
\hline 200819 & $1 \mathrm{OC} 5 \mathrm{P}$ & 7283. & 72847. & 88 & 1.3 & 0.034 & 0.038 & 0.038 & 0.040 & 0.042 & 0.044 \\
\hline 2008123 & $5 \mathrm{OC} 1 \mathrm{P}$ & 0311 . & 052 . & 223 & 3.9 & 0.033 & 0.037 & 0.037 & 0.035 & 0.021 & 0.048 \\
\hline 2008124 & $1 \mathrm{OC} 5 \mathrm{~T}$ & 155751. & 15592. & 141 & 0.8 & 0.130 & 0.152 & 0.152 & 0.160 & 0.171 & 0.002 \\
\hline 2008127 & $2 \mathrm{OC} 5 \mathrm{P}$ & 123511 . & 12360. & 97 & 0.2 & 0.046 & 0.052 & 0.052 & 0.054 & 0.058 & 0.041 \\
\hline 2008129 & $5 \mathrm{OC} 2 \mathrm{P}$ & 15046. & 15150 . & 129 & 0.6 & 0.107 & 0.123 & 0.123 & 0.126 & 0.142 & 0.029 \\
\hline 2008131 & $2 \mathrm{OC} 5 \mathrm{~T}$ & 172237. & 172352 & 150 & 1.0 & 0.129 & 0.150 & 0.150 & 0.158 & 0.169 & 0.003 \\
\hline 200822 & 5 OC $2 \mathrm{~A}$ & 194732. & 194852. & 158 & 1.4 & 0.126 & 0.146 & 0.146 & 0.149 & 0.169 & 0.006 \\
\hline 200824 & $2 \mathrm{OC} 5 \mathrm{~T}$ & 22743 & 2296 & 165 & 1.8 & 0.129 & 0.150 & 0.150 & 0.158 & 0.169 & 0.002 \\
\hline 200827 & 5 OC $2 \mathrm{~A}$ & 03124. & 03250 . & 173 & 2.2 & 0.126 & 0.146 & 0.146 & 0.149 & 0.169 & 0.001 \\
\hline 200828 & $1 \mathrm{EC} 5 \mathrm{~T}$ & 23291. & 23328. & 344 & 3.9 & 1.000 & $* * * * *$ & 0.144 & $* * * * *$ & $* * * * *$ & 0.007 \\
\hline 200829 & $2 \mathrm{OC} 5 \mathrm{~T}$ & 24925 & 25055. & 182 & 2.6 & 0.129 & 0.150 & 0.150 & 0.158 & 0.169 & 0.002 \\
\hline 2008211 & 5 OC $2 \mathrm{~A}$ & 5952. & 51123 . & 182 & 2.9 & 0.126 & 0.146 & 0.146 & 0.149 & 0.169 & 0.021 \\
\hline 2008213 & $2 \mathrm{OC} 5 \mathrm{P}$ & 72436. & 72542 . & 132 & 3.2 & 0.038 & 0.042 & 0.042 & 0.044 & 0.047 & 0.043 \\
\hline 2008215 & $2 \mathrm{OC} 3 \mathrm{~A}$ & 102357 . & 11528 & 5479 & 4.3 & 0.329 & 0.434 & 0.434 & 0.442 & 0.476 & 0.006 \\
\hline 2008215 & 2 OC $3 \mathrm{P}$ & 172456. & 18751. & 4655 & 7.6 & 0.323 & 0.423 & 0.423 & 0.431 & 0.464 & $0.02 *$ \\
\hline 2008218 & $1 \mathrm{OC} 2 \mathrm{P}$ & 234060 . & 234228 . & 175 & 2.8 & 0.052 & 0.058 & 0.058 & 0.062 & 0.089 & 0.056 \\
\hline 2008219 & $3 \mathrm{OC} 1 \mathrm{P}$ & 175159. & 175451. & 345 & 3.7 & 0.393 & 0.542 & 0.542 & 0.529 & 0.424 & 0.021 \\
\hline 2008220 & $2 \mathrm{OC} 1 \mathrm{P}$ & 20597 & 212359 & 3311 & 5.0 & 0.550 & 0.868 & 0.868 & 0.830 & 0.577 & 0.011 \\
\hline 2008221 & $2 \mathrm{OC} 1 \mathrm{P}$ & 193341 . & 194233 . & 1064 & 6.1 & 0.370 & 0.501 & 0.501 & 0.483 & 0.352 & 0.027 \\
\hline 2008221 & $2 \mathrm{OC} 1 \mathrm{~T}$ & 21944 . & 25719 . & 4190 & 2.0 & 0.663 & 1.181 & 1.181 & 1.120 & 0.745 & 0.001 \\
\hline 2008223 & $4 \mathrm{OC} 2 \mathrm{P}$ & 202157. & 202444 . & 334 & 5.6 & 0.089 & 0.102 & 0.102 & 0.109 & 0.172 & 0.051 \\
\hline 2008315 & $1 \mathrm{OC} 5 \mathrm{P}$ & 62543 & 6283. & 278 & 3.9 & 0.039 & 0.043 & 0.043 & 0.045 & 0.048 & 0.042 \\
\hline 2008413 & $5 \mathrm{EC} 1 \mathrm{~A}$ & 55942. & 6345 . & 449 & 4.0 & 0.164 & 0.194 & 0.168 & 0.194 & 0.194 & 0.001 \\
\hline 2008423 & $2 \mathrm{EC} 5 \mathrm{c}$ & & 185953. & & 3.8 & & & & & & 0.1 \\
\hline
\end{tabular}


J.-E. Arlot et al.: Mutual events of the Uranian satellites, Online Material p 12

Table 18. Mutual events of the 2006-2008 period: main events predicted with GUST86 (6/6).

\begin{tabular}{|c|c|c|c|c|c|c|c|c|c|c|c|}
\hline $\begin{array}{l}\text { Date (TT) } \\
\text { of maximum } \\
\text { year mth day } \\
\text { Cols. }\left(\begin{array}{lll}1 & 2 & 3\end{array}\right)\end{array}$ & $\begin{array}{l}\text { Event } \\
\text { (4 } 5567 \text { ) }\end{array}$ & $\begin{array}{l}\text { Begins } \\
\text { at } \\
\mathrm{h} \mathrm{m} \mathrm{s} \\
(8910)\end{array}$ & $\begin{array}{l}\text { Maximum } \\
\mathrm{h} \mathrm{m} \mathrm{s} \\
\left(\begin{array}{lll}1 & 1 & 12\end{array}\right)\end{array}$ & $\begin{array}{l}\text { Dur. } \\
\text { s } \\
\text { (14) }\end{array}$ & $\begin{array}{l}\text { Dist. } \\
\text { (UR) } \\
\text { (15) }\end{array}$ & $\begin{array}{l}\text { Flux } \\
R \\
(16)\end{array}$ & $\begin{array}{l}\text { Magn. } \\
R \\
(17)\end{array}$ & $\begin{array}{l}\text { Magn. } \\
R \\
2 \text { sat } \\
(18)\end{array}$ & $\begin{array}{l}\text { Magn. } \\
V \\
\text { (19) }\end{array}$ & $\begin{array}{l}\text { Magn. } \\
\text { no alb. } \\
\text { (20) }\end{array}$ & $\begin{array}{l}\text { Impact } \\
\text { param. } \\
\left({ }^{\prime \prime}\right) \\
(21)\end{array}$ \\
\hline 200857 & 3 EC 5 P & 133214. & 133611. & 209 & 0.8 & 0.132 & 0.153 & 0.016 & 0.153 & 0.153 & 0.064 \\
\hline 2008529 & 5 EC 3 P & 152851. & 153432 . & 505 & 1.6 & 0.044 & 0.049 & 0.043 & 0.049 & 0.049 & 0.053 \\
\hline 2008715 & $5 \mathrm{EC} 1 \mathrm{~A}$ & 113553. & 114120 . & 605 & 3.9 & 0.165 & 0.195 & 0.169 & 0.195 & 0.195 & 0.021 \\
\hline 2008812 & $1 \mathrm{EC} 5 \mathrm{~T}$ & 221235 . & 22249 & 1317 & 3.2 & 1.000 & $* * * * *$ & 0.144 & $* * * * *$ & $* * * * *$ & 0.021 \\
\hline 2008819 & $5 \mathrm{EC} 2 \mathrm{P}$ & 91657. & 92644 . & 1024 & 1.8 & 0.102 & 0.117 & 0.090 & 0.117 & 0.117 & 0.036 \\
\hline 2008823 & $5 \mathrm{OC} 2 \mathrm{~A}$ & 211658 . & 212722 . & 1304 & 1.7 & 0.126 & 0.146 & 0.146 & 0.149 & 0.169 & 0.024 \\
\hline 20081030 & $5 \mathrm{OC} 4 \mathrm{~A}$ & 16149 & 16617. & 535 & 0.3 & 0.103 & 0.118 & 0.118 & 0.104 & 0.103 & 0.033 \\
\hline 20081213 & $5 \mathrm{OC} 1 \mathrm{~A}$ & 31022. & 31521 . & 597 & 3.8 & 0.256 & 0.322 & 0.322 & 0.298 & 0.171 & 0.018 \\
\hline 20081 & 2 EC $5 \mathrm{P}$ & 17022. & 17739. & 775 & 0.8 & 0.643 & 1.119 & 0.166 & 1.119 & 1.119 & 0.035 \\
\hline 20081223 & $5 \mathrm{OC} 4 \mathrm{~A}$ & 61853. & 62333. & 559 & 0.5 & 0.103 & 0.118 & 0.118 & 0.104 & 0.103 & 0.028 \\
\hline 2009111 & $1 \mathrm{OC} 5 \mathrm{P}$ & 3222 & 3614. & 464 & 3.7 & 0.043 & 0.048 & 0.048 & 0.050 & 0.054 & 0.042 \\
\hline 2009111 & $1 \mathrm{OC} 5 \mathrm{~T}$ & 162944 . & 163620 . & 776 & 3.7 & 0.130 & 0.152 & 0.152 & 0.160 & 0.171 & 0.001 \\
\hline 2009611 & $1 \mathrm{EC} 5 \mathrm{~T}$ & 184757. & 191052. & 2636 & 2.2 & 1.000 & $* * * * *$ & 0.144 & $* * * * *$ & $* * * * *$ & 0.010 \\
\hline 2009122 & $1 \mathrm{EC} 5 \mathrm{~T}$ & 84439 . & 9629. & 2504 & 1.9 & 1.000 & $* * * * *$ & 0.144 & $* * * * *$ & $* * * * *$ & 0.021 \\
\hline
\end{tabular}

Table 19. Mutual events of the 2006-2008 period: eventual events predicted with LA06 and GUST86 (1/10).

\begin{tabular}{|c|c|c|c|c|}
\hline $\begin{array}{l}\text { Date (TT) } \\
\text { of maximum } \\
\text { year mth day } \\
\text { Cols. }\left(\begin{array}{lll}1 & 2 & 3\end{array}\right)\end{array}$ & $(4567)$ & $\begin{array}{l}\text { maximum } \\
\text { LA06 } \\
\mathrm{h} \mathrm{m} \mathrm{s} \\
(8910)\end{array}$ & $\begin{array}{l}\operatorname{maximum} \\
\text { GUST86 } \\
\mathrm{h} \mathrm{m} \mathrm{s} \\
\left(\begin{array}{lll}1 & 12 & 13\end{array}\right)\end{array}$ & $\begin{array}{l}\text { (UR) } \\
\text { (14) }\end{array}$ \\
\hline 2006518 & $5 \mathrm{Oc} 1 \mathrm{c}$ & 1738. & 1751. & 3.7 \\
\hline 2006524 & $1 \mathrm{Oc} 5 \mathrm{c}$ & 85347. & 85353. & 3.4 \\
\hline 200669 & $5 \mathrm{Oc} 1 \mathrm{c}$ & 17526. & 17526. & 3.9 \\
\hline 2006628 & $1 \mathrm{Oc} 5 \mathrm{c}$ & 161157. & 16125. & 3.1 \\
\hline 2006731 & $1 \mathrm{Oc} 5 \mathrm{c}$ & 93552. & 93417. & 3.6 \\
\hline 200686 & $5 \mathrm{Oc} 1 \mathrm{c}$ & 161323 . & 161320 . & 3.9 \\
\hline 200722 & $1 \mathrm{Ec} 5 \mathrm{c}$ & 212757 . & 212741 . & 3.9 \\
\hline 200729 & $5 \mathrm{Ec} 1 \mathrm{c}$ & 4589. & 45818. & 3.8 \\
\hline 2007225 & $1 \mathrm{Ec} 5 \mathrm{c}$ & 141551 . & 141433 . & 3.7 \\
\hline 200733 & $5 \mathrm{Ec} 1 \mathrm{c}$ & 21325 & 21319. & 3.9 \\
\hline 200733 & $5 \mathrm{Oc} 1 \mathrm{c}$ & 2137. & 2132. & 3.9 \\
\hline 2007310 & $1 \mathrm{Ec} 5 \mathrm{c}$ & 43428 & 43426 . & 3.8 \\
\hline 2007316 & $5 \mathrm{Ec} 1 \mathrm{c}$ & 121526 . & 121540 . & 3.5 \\
\hline 2007319 & 5 Oc $1 \mathrm{c}$ & 41819. & 41840 & 1.1 \\
\hline 2007322 & $1 \mathrm{Ec} 5 \mathrm{c}$ & 2060. & 2069. & 3.2 \\
\hline 2007322 & 1 Oc $5 c$ & 20455 . & 2052 . & 3.2 \\
\hline 200749 & $1 \mathrm{Oc} 5 \mathrm{c}$ & 204510 & 204527 . & 1.5 \\
\hline 2007411 & 3 Oc $5 c$ & 144041 . & 143948 . & 3.0 \\
\hline 2007413 & 5 Oc $4 \mathrm{c}$ & 172917. & 172826. & 2.9 \\
\hline 2007416 & $5 \mathrm{Oc} 1 \mathrm{P}$ & 44155 & 44215 & 2.1 \\
\hline 2007418 & $1 \mathrm{Oc} 2 \mathrm{P}$ & 472. & 35736 . & 4.8 \\
\hline 2007418 & $1 \mathrm{Oc} 2 \mathrm{P}$ & 74826. & 74826. & 2.7 \\
\hline 2007419 & $1 \mathrm{Oc} 2 \mathrm{c}$ & 21029 . & 2816. & 6.2 \\
\hline 2007420 & 2 Oc $5 c$ & 85231. & 8479. & 3.1 \\
\hline 2007421 & 3 Oc $2 c$ & 124614. & 12452 & 8.9 \\
\hline 2007424 & 1 Oc $5 c$ & 14139. & 135835 . & 3.4 \\
\hline 2007428 & $2 \mathrm{Oc} 1 \mathrm{c}$ & 18210. & 182017. & 1.6 \\
\hline 2007428 & $3 \mathrm{Oc} 1 \mathrm{c}$ & 221446 . & 221324 . & 4.1 \\
\hline 2007429 & 3 Oc $5 c$ & 144940 . & 14491 & 2.2 \\
\hline 200753 & $5 \mathrm{Ec} 1 \mathrm{P}$ & 11226 & 112225 . & 2.3 \\
\hline 200755 & $1 \mathrm{Oc} 5 \mathrm{c}$ & 42138 . & 42149 & 3.4 \\
\hline
\end{tabular}


J.-E. Arlot et al.: Mutual events of the Uranian satellites, Online Material p 13

Table 20. Mutual events of the 2006-2008 period: eventual events predicted with LA06 and GUST86 (2/10).

\begin{tabular}{|c|c|c|c|c|}
\hline $\begin{array}{l}\text { Date (TT) } \\
\text { of maximum } \\
\text { year mth day } \\
\text { Cols. }\left(\begin{array}{lll}1 & 2 & 3\end{array}\right)\end{array}$ & (4 567 ) & $\begin{array}{l}\text { Maximum } \\
\text { LA06 } \\
\text { h m s } \\
\left(\begin{array}{lll}8 & 9 & 10\end{array}\right)\end{array}$ & $\begin{array}{l}\text { Maximum } \\
\text { GUST86 } \\
\mathrm{h} \mathrm{m} \mathrm{s} \\
\left(\begin{array}{lll}1 & 1 & 12\end{array}\right)\end{array}$ & $\begin{array}{l}\text { (UR) } \\
\text { (14) }\end{array}$ \\
\hline 200758 & 3 Oc $1 \mathrm{c}$ & 102630. & 10257 & 3.5 \\
\hline 200759 & 3 Oc $4 c$ & 122026 . & 121729 . & 13.4 \\
\hline 200759 & $1 \mathrm{Oc} 2 \mathrm{c}$ & 15305. & 152911. & 4.2 \\
\hline 200759 & $1 \mathrm{Ec} 5 \mathrm{c}$ & 191940 . & 191955. & 1.9 \\
\hline 2007510 & $1 \mathrm{Oc} 4 \mathrm{c}$ & 93259. & 93118. & 5.4 \\
\hline 2007511 & $1 \mathrm{Oc} 4 \mathrm{c}$ & 14228 . & 141416 . & 4.8 \\
\hline 2007511 & $5 \mathrm{Oc} 1 \mathrm{c}$ & 12540 . & 12550 & 3.7 \\
\hline 2007512 & $1 \mathrm{Oc} 2 \mathrm{c}$ & 22561. & 22552. & 5.7 \\
\hline 2007513 & $5 \mathrm{Ec} 1 \mathrm{c}$ & 111630 . & 111642 . & 3.5 \\
\hline 2007515 & $2 \mathrm{Oc} 1 \mathrm{c}$ & 213453. & 21347. & 4.7 \\
\hline 2007516 & $5 \mathrm{Ec} 1 \mathrm{c}$ & 31631. & 31653 . & 1.2 \\
\hline 2007519 & $1 \mathrm{Ec} 5 \mathrm{c}$ & 1951. & 1958. & 3.3 \\
\hline 2007522 & $1 \mathrm{Ec} 5 \mathrm{c}$ & 111553. & 11169. & 0.8 \\
\hline 2007523 & $5 \mathrm{Oc} 1 \mathrm{P}$ & 14958. & 14518. & 3.0 \\
\hline 2007526 & $5 \mathrm{Ec} 1 \mathrm{c}$ & 25522 . & 25541 . & 2.8 \\
\hline 200763 & $5 \mathrm{Oc} 1 \mathrm{c}$ & 34846 . & 3491. & 3.4 \\
\hline 200765 & $5 \mathrm{Ec} 1 \mathrm{c}$ & 3749. & 3751. & 3.8 \\
\hline 200769 & $1 \mathrm{Oc} 5 \mathrm{P}$ & 11352. & 11357. & 3.7 \\
\hline 2007611 & 1 Ec $5 c$ & 10475. & 10475. & 3.7 \\
\hline 2007615 & $5 \mathrm{Oc} 1 \mathrm{c}$ & 191036. & 191039. & 3.9 \\
\hline 2007617 & $5 \mathrm{Ec} 1 \mathrm{c}$ & 183159. & 183214. & 3.2 \\
\hline 2007620 & $5 \mathrm{Oc} 2 \mathrm{c}$ & 12144 & 1210 & 3.9 \\
\hline 2007621 & $1 \mathrm{Oc} 5 \mathrm{c}$ & 141411. & 14136. & 2.6 \\
\hline 2007622 & $2 \mathrm{Oc} 1 \mathrm{c}$ & 64151. & 63857 . & 5.8 \\
\hline 2007622 & 2 Oc $5 c$ & 31555 . & 31447. & 3.9 \\
\hline 2007623 & 5 Ec $2 c$ & 125524 . & 125410 . & 3.9 \\
\hline 2007624 & 1 Ec $5 \mathrm{c}$ & 22418 & 22427 & 2.9 \\
\hline 2007625 & $2 \operatorname{Ec} 5 c$ & 14544 . & 14538. & 3.9 \\
\hline 2007627 & 5 Ec $2 P$ & 165422 . & 165350 . & 3.6 \\
\hline 2007630 & $5 \mathrm{Ec} 1 \mathrm{c}$ & 101720 . & 101739 . & 2.4 \\
\hline 200773 & $5 \mathrm{Oc} 4 \mathrm{P}$ & 165634 . & 17128 & 0.8 \\
\hline
\end{tabular}


J.-E. Arlot et al.: Mutual events of the Uranian satellites, Online Material p 14

Table 21. Mutual events of the 2006-2008 period: eventual events predicted with LA06 and GUST86 (3/10).

\begin{tabular}{|c|c|c|c|c|}
\hline $\begin{array}{l}\text { Date (TT) } \\
\text { of maximum } \\
\text { year mth day } \\
\text { Cols. }\left(\begin{array}{lll}1 & 2 & 3\end{array}\right)\end{array}$ & $(4567)$ & $\begin{array}{l}\text { maximum } \\
\text { LA06 } \\
\mathrm{h} \mathrm{m} \mathrm{s} \\
(8910)\end{array}$ & $\begin{array}{l}\operatorname{maximum} \\
\text { GUST86 } \\
\mathrm{h} \mathrm{m} \mathrm{s} \\
\left(\begin{array}{lll}11 & 12 & 13\end{array}\right)\end{array}$ & $\begin{array}{l}\text { (UR) } \\
\text { (14) }\end{array}$ \\
\hline 200774 & $1 \mathrm{Ec} 5 \mathrm{c}$ & 24035 & 24024 & 3.5 \\
\hline 200776 & 1 Ec $5 c$ & 181423 . & 181436 . & 13.4 \\
\hline 200778 & $5 \mathrm{Oc} 1 \mathrm{c}$ & 1146. & 11418. & 4.2 \\
\hline 2007713 & $5 \mathrm{Ec} 1 \mathrm{c}$ & 2111 . & 21121 . & 1.9 \\
\hline 2007714 & $1 \mathrm{Oc} 5 \mathrm{c}$ & 184329 . & 184328 & 5.4 \\
\hline 2007719 & $1 \mathrm{Ec} 5 \mathrm{c}$ & 101012 . & 101029 . & 4.8 \\
\hline 2007722 & $5 \mathrm{Ec} 2 \mathrm{c}$ & 21051. & 21045 & 3.7 \\
\hline 2007724 & $2 \operatorname{Ec} 5 c$ & 232411 . & 23248 . & 5.7 \\
\hline 2007725 & $5 \mathrm{Ec} 1 \mathrm{c}$ & 18839. & 1891. & 3.5 \\
\hline 2007728 & $5 \mathrm{Ec} 1 \mathrm{c}$ & 103840 . & 10392. & 4.7 \\
\hline 2007731 & $1 \mathrm{Oc} 2 \mathrm{c}$ & 153742 . & 153640 . & 1.2 \\
\hline 2007731 & $5 \mathrm{Oc} 1 \mathrm{c}$ & 24740 & 24756 & 3.3 \\
\hline 200782 & $5 \mathrm{Ec} 1 \mathrm{c}$ & 21051. & 21048 & 0.8 \\
\hline 200783 & $1 \mathrm{Ec} 5 \mathrm{c}$ & 183751. & 183810 . & 3.0 \\
\hline 200783 & 3 Oc $5 c$ & 124624 . & 124349 . & 2.8 \\
\hline 200786 & $2 \mathrm{Oc} 1 \mathrm{P}$ & 21236 & 212210 . & 3.4 \\
\hline 200787 & $1 \mathrm{Oc} 3 \mathrm{c}$ & 8948. & 8154. & 3.8 \\
\hline 200787 & $5 \mathrm{Ec} 1 \mathrm{c}$ & 1088. & 10831 . & 3.7 \\
\hline 200788 & $1 \mathrm{Oc} 2 \mathrm{c}$ & 135813. & 135721. & 3.7 \\
\hline 200788 & $1 \mathrm{Oc} 3 \mathrm{c}$ & 21652 & 21420 & 3.9 \\
\hline 2007810 & $2 \mathrm{Oc} 1 \mathrm{c}$ & 51655. & 51611. & 3.2 \\
\hline 2007810 & $5 \mathrm{Ec} 1 \mathrm{c}$ & 23536 . & 23557 . & 3.9 \\
\hline 2007812 & $3 \mathrm{Oc} 1 \mathrm{c}$ & 44743 & 44619 & 2.6 \\
\hline 2007812 & 3 Oc 4 P & 115950. & 115647. & 5.8 \\
\hline 2007812 & 5 Oc $2 c$ & 204433 . & 204413 . & 3.9 \\
\hline 2007813 & $1 \mathrm{Ec} 5 \mathrm{c}$ & 18834. & 18853. & 3.9 \\
\hline 2007815 & $5 \mathrm{Ec} 3 \mathrm{c}$ & 235923 . & 235852 & 2.9 \\
\hline 2007817 & 5 Oc $2 c$ & 11423. & 11353. & 3.9 \\
\hline 2007818 & 4 Oc $3 c$ & 4489. & 44529 . & 3.6 \\
\hline 2007820 & $5 \mathrm{Ec} 1 \mathrm{c}$ & 284 & 2827 & 2.4 \\
\hline 2007820 & 3 Oc $1 \mathrm{P}$ & 53138 . & 53021. & 0.8 \\
\hline
\end{tabular}


J.-E. Arlot et al.: Mutual events of the Uranian satellites, Online Material p 15

Table 22. Mutual events of the 2006-2008 period: eventual events predicted with LA06 and GUST86 (4/10).

\begin{tabular}{|c|c|c|c|c|}
\hline $\begin{array}{l}\text { Date (TT) } \\
\text { of maximum } \\
\text { year mth day } \\
\text { Cols. }\left(\begin{array}{lll}1 & 2 & 3\end{array}\right)\end{array}$ & (4 567 ) & $\begin{array}{l}\text { Maximum } \\
\text { LA06 } \\
\text { h m s } \\
\left(\begin{array}{lll}8 & 9 & 10\end{array}\right)\end{array}$ & $\begin{array}{l}\text { Maximum } \\
\text { GUST86 } \\
\mathrm{h} \mathrm{m} \mathrm{s} \\
\left(\begin{array}{lll}1 & 1 & 12\end{array}\right)\end{array}$ & $\begin{array}{l}\text { (UR) } \\
\text { (14) }\end{array}$ \\
\hline 2007820 & 3 Oc $2 c$ & 172911. & 17277 & 1.4 \\
\hline 2007821 & $1 \mathrm{Oc} 2 \mathrm{c}$ & 23057. & 2306. & 2.3 \\
\hline 2007822 & $2 \mathrm{Oc} 1 \mathrm{c}$ & 174611 . & 174526 . & 2.4 \\
\hline 2007822 & $5 \mathrm{Oc} 1 \mathrm{c}$ & 182655 . & 182713 . & 2.8 \\
\hline 2007823 & $2 \mathrm{Oc} 3 \mathrm{c}$ & 232857. & 232617 . & 9.1 \\
\hline 2007824 & $5 \mathrm{Ec} 2 \mathrm{c}$ & 16498. & 164812 . & 3.9 \\
\hline 2007824 & 5 Ec $1 P$ & 184113. & 184027. & 3.8 \\
\hline 2007825 & $1 \mathrm{Ec} 2 \mathrm{c}$ & 72330 . & 73527. & 3.1 \\
\hline 2007826 & 1 Ec $5 c$ & 1089. & 10828 & 0.6 \\
\hline 2007826 & $2 \operatorname{Ec} 5 \mathrm{c}$ & 185234. & 185148. & 3.8 \\
\hline 2007827 & 5 Oc $4 c$ & 1449. & 1410. & 2.3 \\
\hline 2007829 & $1 \mathrm{Oc} 5 \mathrm{c}$ & 22035. & 22048 . & 3.2 \\
\hline 2007830 & $2 \mathrm{Oc} 1 \mathrm{c}$ & 172154 . & 172034 . & 6.3 \\
\hline 200792 & $5 \operatorname{Ec} 3 c$ & 41733. & 41541 & 3.9 \\
\hline 200792 & $5 \mathrm{Oc} 3 \mathrm{c}$ & 41758. & 4164 & 3.9 \\
\hline 200798 & $1 \mathrm{Oc} 5 \mathrm{P}$ & 2611. & 2629 . & 1.7 \\
\hline 2007914 & $5 \mathrm{Oc} 1 \mathrm{c}$ & 10353. & 10413. & 2.3 \\
\hline 2007914 & $5 \mathrm{Oc} 2 \mathrm{c}$ & 153953. & 153947. & 0.5 \\
\hline 2007915 & 3 Ec $5 c$ & 95933. & 95855. & 1.7 \\
\hline 2007915 & 3 Oc $5 \mathrm{P}$ & 10054. & 10017. & 1.7 \\
\hline 2007920 & $1 \mathrm{Ec} 5 \mathrm{c}$ & 175937. & 175952. & 2.7 \\
\hline 2007920 & $5 \operatorname{Ec} 3 c$ & 34032 . & 33960. & 0.8 \\
\hline 2007921 & $5 \mathrm{Oc} 1 \mathrm{c}$ & 17921. & 17944 . & 0.4 \\
\hline 2007922 & $1 \mathrm{Oc} 5 \mathrm{P}$ & 182731 . & 182616 . & 3.8 \\
\hline 2007923 & $3 \operatorname{Ec} 5 c$ & 235140 . & 235040 . & 3.2 \\
\hline 2007924 & $5 \mathrm{Oc} 1 \mathrm{c}$ & 93956. & 94018. & 0.6 \\
\hline 2007927 & $5 \mathrm{Ec} 1 \mathrm{c}$ & 15251. & 1538. & 3.2 \\
\hline
\end{tabular}


J.-E. Arlot et al.: Mutual events of the Uranian satellites, Online Material p 16

Table 23. Mutual events of the 2006-2008 period: eventual events predicted with LA06 and GUST86 (5/10).

\begin{tabular}{|c|c|c|c|c|}
\hline $\begin{array}{l}\text { Date (TT) } \\
\text { of maximum } \\
\text { year mth day } \\
\text { Cols. }\left(\begin{array}{lll}1 & 2 & 3\end{array}\right)\end{array}$ & $(4567)$ & $\begin{array}{l}\text { Maximum } \\
\text { LA06 } \\
\mathrm{h} \mathrm{m} \mathrm{s} \\
(8910)\end{array}$ & $\begin{array}{l}\text { Maximum } \\
\text { GUST86 } \\
\text { h m s } \\
\left(\begin{array}{lll}11 & 12 & 13\end{array}\right)\end{array}$ & $\begin{array}{l}\text { (UR) } \\
\text { (14) }\end{array}$ \\
\hline 2007929 & $2 \operatorname{Ec} 5 c$ & 83020. & 83016. & 0.5 \\
\hline 2007930 & 1 Ec $5 c$ & 173852. & 173910 . & 1.1 \\
\hline 2007101 & $5 \mathrm{Ec} 2 \mathrm{c}$ & 105459. & 105451. & 0.9 \\
\hline 2007101 & $5 \mathrm{Oc} 1 \mathrm{c}$ & 164455 . & 164516 . & 2.1 \\
\hline 2007102 & 3 Ec $5 c$ & 151714 . & 151324 . & 3.9 \\
\hline 2007103 & $2 \operatorname{Ec} 5 \mathrm{c}$ & 131724 . & 131721. & 1.3 \\
\hline 2007105 & $1 \mathrm{Oc} 5 \mathrm{P}$ & 85510. & 8556. & 3.8 \\
\hline 2007105 & 5 Ec $2 P$ & 154120 . & 154112 . & 1.7 \\
\hline 2007105 & $5 \mathrm{Ec} 4 \mathrm{c}$ & 212726 . & 212016 . & 1.5 \\
\hline 2007107 & $5 \mathrm{Ec} 1 \mathrm{c}$ & 13743. & 1384. & 1.7 \\
\hline 20071011 & $2 \operatorname{Ec} 5 \mathrm{c}$ & 224122 & 22419 & 2.8 \\
\hline 20071011 & $3 \mathrm{Ec} 2 \mathrm{c}$ & 103815. & 104312 . & 2.8 \\
\hline 20071013 & 1 Ec $5 \mathrm{c}$ & 93613. & 93631. & 2.2 \\
\hline 20071014 & 5 Oc $1 \mathrm{c}$ & 8432. & 84325 . & 1.1 \\
\hline 20071019 & 5 Ec $1 P$ & 173235 . & 173255 . & 2.7 \\
\hline 20071019 & $5 \mathrm{Ec} 4 \mathrm{c}$ & 192330 . & 192253. & 1.5 \\
\hline 20071021 & $1 \mathrm{Ec} 2 \mathrm{P}$ & 14236 & 13593. & 5.6 \\
\hline 20071021 & $5 \mathrm{Ec} 2 \mathrm{c}$ & 171823 . & 171619 . & 3.9 \\
\hline 20071022 & $1 \mathrm{Ec} 2 \mathrm{c}$ & 132353. & 132111. & 6.0 \\
\hline 20071024 & $5 \mathrm{Oc} 1 \mathrm{c}$ & 82256. & 82316 & 2.7 \\
\hline 20071027 & $2 \mathrm{Ec} 1 \mathrm{c}$ & 175156. & 175025 . & 6.3 \\
\hline 20071028 & $1 \mathrm{Oc} 5 \mathrm{c}$ & 1322. & 133. & 4.0 \\
\hline 2007111 & $5 \mathrm{Ec} 1 \mathrm{c}$ & 91749. & 9184. & 3.5 \\
\hline 2007112 & $1 \mathrm{Ec} 2 \mathrm{c}$ & 2366. & 23453. & 6.3 \\
\hline 2007113 & $5 \mathrm{Oc} 1 \mathrm{c}$ & 83110 & 83117. & 3.8 \\
\hline 2007118 & 4 Ec $5 c$ & 72725 . & 72531 . & 3.9 \\
\hline 2007119 & $2 \mathrm{Ec} 1 \mathrm{c}$ & 4503. & 44860 & 6.0 \\
\hline 20071110 & 1 Ec $3 \mathrm{c}$ & 14518. & 144747 . & 6.3 \\
\hline 20071111 & 1 Ec $3 \mathrm{c}$ & 204613 . & 204331 . & 6.2 \\
\hline 20071115 & $1 \mathrm{Ec} 2 \mathrm{P}$ & 104410 . & 10438. & 5.7 \\
\hline 20071115 & $3 \mathrm{Ec} 1 \mathrm{c}$ & 231919. & 231754 . & 3.6 \\
\hline 20071117 & $1 \mathrm{Ec} 5 \mathrm{c}$ & 17746. & 1782. & 2.6 \\
\hline 20071118 & $2 \mathrm{Ec} 1 \mathrm{c}$ & 92655. & 9266. & 4.8 \\
\hline
\end{tabular}


J.-E. Arlot et al.: Mutual events of the Uranian satellites, Online Material p 17

Table 24. Mutual events of the 2006-2008 period: eventual events predicted with LA06 and GUST86 (6/10).

\begin{tabular}{|c|c|c|c|c|}
\hline $\begin{array}{l}\text { Date (TT) } \\
\text { of maximum } \\
\text { year mth day } \\
\text { Cols. }\left(\begin{array}{llll}1 & 2 & 3\end{array}\right)\end{array}$ & $(4567)$ & $\begin{array}{l}\text { Maximum } \\
\text { LA06 } \\
\text { h m s } \\
(8910)\end{array}$ & $\begin{array}{l}\text { Maximum } \\
\text { GUST86 } \\
\text { h m s } \\
\left(\begin{array}{lll}1 & 1 & 12\end{array}\right)\end{array}$ & $\begin{array}{l}\text { (UR) } \\
\text { (14) }\end{array}$ \\
\hline 20071119 & $2 \mathrm{Ec} 3 \mathrm{c}$ & 05816. & 05519. & 9.2 \\
\hline 20071121 & $4 \mathrm{Ec} 2 \mathrm{c}$ & 213633 . & 21393. & 2.6 \\
\hline 20071124 & $3 \mathrm{Ec} 1 \mathrm{c}$ & 044 . & 0244 . & 2.4 \\
\hline 20071124 & 3 Ec $5 c$ & 162759. & 162635 . & 3.7 \\
\hline 20071124 & $5 \mathrm{Ec} 1 \mathrm{c}$ & 1222 . & 1240 & 3.0 \\
\hline 20071128 & $1 \mathrm{Ec} 4 \mathrm{c}$ & 63053. & 62641 & 6.4 \\
\hline 20071128 & $1 \mathrm{Ec} 4 \mathrm{c}$ & 15483. & 15534. & 2.6 \\
\hline 20071129 & $1 \mathrm{Ec} 4 \mathrm{P}$ & 15173. & 151453. & 5.7 \\
\hline 2007126 & 4 Ec 5 c & 1486. & 14724 & 2.8 \\
\hline 2007126 & $5 \mathrm{Ec} 1 \mathrm{c}$ & 163948 . & 163959. & 3.7 \\
\hline 20071213 & 2 Ec $5 c$ & 3421 & 345. & 3.0 \\
\hline 20071215 & $5 \mathrm{Ec} 2 \mathrm{c}$ & 5212 & 52042 . & 3.3 \\
\hline 20071216 & $2 \mathrm{Ec} 3 \mathrm{c}$ & 13583. & 13561. & 5.1 \\
\hline 20071218 & $5 \mathrm{Ec} 1 \mathrm{c}$ & 1874. & 18237. & 3.4 \\
\hline 20071219 & 5 Ec $2 \mathrm{c}$ & 94041. & 93955. & 3.8 \\
\hline 20071220 & $2 \operatorname{Ec} 5 \mathrm{c}$ & 195528 . & 19529. & 3.8 \\
\hline 20071221 & $3 \mathrm{Ec} 1 \mathrm{c}$ & 01958. & 01756. & 6.0 \\
\hline 20071222 & $1 \mathrm{Ec} 2 \mathrm{c}$ & 234811 . & 234719 . & 2.5 \\
\hline 20071224 & 5 Ec $3 P$ & 92829 . & 91833 & 3.6 \\
\hline 20071225 & $1 \mathrm{Ec} 3 \mathrm{c}$ & 21426 & 21258 & 2.8 \\
\hline 20071225 & $1 \mathrm{Ec} 4 \mathrm{c}$ & 12541. & 125229 & 3.0 \\
\hline 20071225 & $2 \mathrm{Ec} 4 \mathrm{c}$ & 13215. & 1300. & 3.0 \\
\hline 20071227 & $1 \mathrm{Ec} 2 \mathrm{c}$ & 144846 . & 144754 & 2.8 \\
\hline 20071227 & $1 \mathrm{Oc} 5 \mathrm{c}$ & 153132. & 153146 . & 2.4 \\
\hline 20071229 & $2 \mathrm{Ec} 1 \mathrm{c}$ & 6532. & 6444 & 1.8 \\
\hline 20071229 & $5 \mathrm{Ec} 1 \mathrm{c}$ & 83018 . & 83034. & 3.4 \\
\hline 20071231 & $4 \mathrm{Ec} 2 \mathrm{c}$ & 233351 . & 233138 & 5.6 \\
\hline 20071231 & $5 \mathrm{Oc} 1 \mathrm{c}$ & 74726 . & 74729 . & 3.9 \\
\hline 200811 & 4 Ec $1 \mathrm{c}$ & 03628 . & 03446 . & 5.2 \\
\hline 200812 & $2 \mathrm{Ec} 1 \mathrm{c}$ & 21140 & 21052. & 3.4 \\
\hline 200812 & $5 \mathrm{Oc} 1 \mathrm{c}$ & 232843 . & 23295 & 1.8 \\
\hline 200814 & $1 \mathrm{Ec} 2 \mathrm{c}$ & 122225 . & 122133 . & 1.2 \\
\hline
\end{tabular}


J.-E. Arlot et al.: Mutual events of the Uranian satellites, Online Material p 18

Table 25. Mutual events of the 2006-2008 period: eventual events predicted with LA06 and GUST86 (7/10).

\begin{tabular}{|c|c|c|c|c|}
\hline $\begin{array}{l}\text { Date (TT) } \\
\text { of maximum } \\
\text { year mth day } \\
\text { Cols. }\left(\begin{array}{llll}1 & 2 & 3\end{array}\right)\end{array}$ & (4 567 ) & $\begin{array}{l}\text { Maximum } \\
\text { LA06 } \\
\text { h m s } \\
(8910)\end{array}$ & $\begin{array}{l}\text { Maximum } \\
\text { GUST86 } \\
\mathrm{h} \text { m s } \\
\left(\begin{array}{lll}1 & 1 & 13\end{array}\right)\end{array}$ & $\begin{array}{l}\text { Dist. } \\
\text { (UR) } \\
\text { (14) }\end{array}$ \\
\hline 200816 & $2 \mathrm{Ec} 1 \mathrm{c}$ & 5439 & 5327 & 6.2 \\
\hline 200817 & $1 \mathrm{Ec} 4 \mathrm{c}$ & 18443 . & 173119. & 5.5 \\
\hline 200817 & $2 \mathrm{Ec} 4 \mathrm{c}$ & 11933. & 11655 & 8.3 \\
\hline 200817 & $3 \mathrm{Ec} 1 \mathrm{c}$ & 23657. & 3045. & 2.3 \\
\hline 200817 & $3 \mathrm{Ec} 1 \mathrm{c}$ & 10154 . & 9507. & 5.9 \\
\hline 200819 & 1 Ec $2 \mathrm{c}$ & 31811 . & 31715 . & 4.0 \\
\hline 2008110 & $5 \mathrm{Ec} 1 \mathrm{c}$ & 23540 & 23542 & 3.9 \\
\hline 2008112 & $1 \mathrm{Ec} 2 \mathrm{c}$ & 105028 . & 104923. & 5.9 \\
\hline 2008112 & $5 \mathrm{Oc} 1 \mathrm{P}$ & 231618 . & 231634 . & 3.3 \\
\hline 2008113 & $4 \operatorname{Ec} 3 \mathrm{c}$ & 65711. & 65413 & 15.6 \\
\hline 2008114 & $4 \operatorname{Ec} 2 \mathrm{c}$ & 22049 & 2192 & 9.0 \\
\hline 2008114 & 4 Ec $2 P$ & 201023 . & 201243 & 1.7 \\
\hline 2008115 & $2 \mathrm{Ec} 1 \mathrm{c}$ & 92611. & 92521. & 4.5 \\
\hline 2008115 & $5 \mathrm{Oc} 1 \mathrm{c}$ & 152747. & 15289. & 0.7 \\
\hline 2008115 & 3 Ec $5 c$ & 224032 . & 223831 . & 3.9 \\
\hline 2008116 & 1 Ec $5 \mathrm{c}$ & 181555 . & 18130 & 3.1 \\
\hline 2008119 & 1 Oc $5 \mathrm{c}$ & 7103. & 71016 . & 2.9 \\
\hline 2008121 & $1 \mathrm{Ec} 2 \mathrm{c}$ & 15398. & 15388. & 5.0 \\
\hline 2008122 & $5 \mathrm{Ec} 4 \mathrm{c}$ & 72023 . & 71818 & 3.9 \\
\hline 2008127 & $2 \mathrm{Ec} 1 \mathrm{c}$ & 213924. & 213833 . & 5.5 \\
\hline 2008128 & $5 \mathrm{Oc} 3 \mathrm{c}$ & 93640 . & 9368. & 1.4 \\
\hline 2008129 & 1 Oc $5 c$ & 7266. & 72554. & 3.9 \\
\hline 2008130 & $5 \mathrm{Oc} 1 \mathrm{c}$ & 235756 . & 235819 . & 1.4 \\
\hline 200822 & 3 Oc $5 \mathrm{c}$ & 3610 . & 3539. & 1.2 \\
\hline 200822 & $5 \mathrm{Ec} 1 \mathrm{c}$ & 155258. & 155310 . & 3.7 \\
\hline 200823 & $1 \mathrm{Ec} 2 \mathrm{c}$ & 34314 & 3428. & 5.8 \\
\hline 200825 & $5 \mathrm{Oc} 3 \mathrm{c}$ & 232342 & 232248 & 2.9 \\
\hline 200826 & 1 Oc $5 \mathrm{c}$ & 75640 . & 75659. & 1.9 \\
\hline
\end{tabular}


J.-E. Arlot et al.: Mutual events of the Uranian satellites, Online Material p 19

Table 26. Mutual events of the 2006-2008 period: eventual events predicted with LA06 and GUST86 (8/10).

\begin{tabular}{|c|c|c|c|c|}
\hline $\begin{array}{l}\text { Date (TT) } \\
\text { of maximum } \\
\text { year mth day } \\
\text { Cols. }\left(\begin{array}{lll}1 & 2 & 3\end{array}\right)\end{array}$ & $(4567)$ & $\begin{array}{l}\text { Maximum } \\
\text { LA06 } \\
\text { h m s } \\
\left(\begin{array}{lll}8 & 9 & 10\end{array}\right)\end{array}$ & $\begin{array}{l}\text { Maximum } \\
\text { GUST86 } \\
\mathrm{h} \mathrm{m} \mathrm{s} \\
\left(\begin{array}{lll}1 & 1 & 12\end{array}\right)\end{array}$ & $\begin{array}{l}\text { (UR) } \\
\text { (14) }\end{array}$ \\
\hline 200829 & $2 \mathrm{Ec} 1 \mathrm{c}$ & 92726. & 92624 & 6.1 \\
\hline 2008214 & $1 \mathrm{Oc} 3 \mathrm{c}$ & 91956. & 91925. & 6.2 \\
\hline 2008214 & $2 \mathrm{Oc} 3 \mathrm{c}$ & 23844 . & 23553 . & 9.1 \\
\hline 2008214 & 5 Oc $3 c$ & 14202. & 141735 . & 3.9 \\
\hline 2008215 & $1 \mathrm{Ec} 2 \mathrm{c}$ & 15349 . & 15218 & 6.3 \\
\hline 2008215 & $1 \mathrm{Oc} 2 \mathrm{P}$ & 15539. & 1547. & 6.3 \\
\hline 2008215 & $1 \mathrm{Oc} 3 \mathrm{P}$ & 152319 . & 152037. & 6.3 \\
\hline 2008215 & 5 Oc $2 \mathrm{P}$ & 94139. & 9418. & 3.5 \\
\hline 2008215 & $5 \mathrm{Oc} 3 \mathrm{P}$ & 93423. & 93311. & 3.6 \\
\hline 2008217 & $2 \mathrm{Oc} 1 \mathrm{c}$ & 82533 & 82447 & 1.7 \\
\hline 2008217 & 2 Oc $5 c$ & 114753. & 114718 . & 3.7 \\
\hline 2008218 & $1 \mathrm{Oc} 4 \mathrm{c}$ & 8395. & 83714. & 5.2 \\
\hline 2008218 & $3 \mathrm{Oc} 4 \mathrm{c}$ & 142843 . & 142539 . & 7.6 \\
\hline 2008218 & $5 \mathrm{Ec} 2 \mathrm{c}$ & 223933. & 223333. & 3.4 \\
\hline 2008218 & $5 \mathrm{Oc} 2 \mathrm{c}$ & 222957. & 222513 . & 3.5 \\
\hline 2008218 & $5 \mathrm{Oc} 4 \mathrm{c}$ & 5334. & 525. & 3.7 \\
\hline 2008219 & $5 \mathrm{Ec} 2 \mathrm{c}$ & 134942 . & 134851. & 3.9 \\
\hline 2008220 & $1 \mathrm{Oc} 5 \mathrm{c}$ & 23493 & 234814 . & 3.9 \\
\hline 2008220 & $2 \mathrm{Ec} 1 \mathrm{c}$ & 212846 . & 212244 . & 5.0 \\
\hline 2008221 & $2 \mathrm{Ec} 1 \mathrm{c}$ & 21244 & 2588 & 2.4 \\
\hline 2008221 & $2 \mathrm{Ec} 1 \mathrm{c}$ & 194311. & 19413. & 6.1 \\
\hline 2008221 & $2 \operatorname{Ec} 5 c$ & 15343. & 153226. & 3.9 \\
\hline 2008223 & $1 \mathrm{Oc} 2 \mathrm{P}$ & 144241 . & 144147 . & 2.4 \\
\hline 2008224 & 2 Oc $3 c$ & 141420 . & 141149 . & 8.9 \\
\hline 2008224 & $4 \mathrm{Oc} 1 \mathrm{c}$ & 202851. & 202726 . & 2.7 \\
\hline 2008225 & $2 \mathrm{Oc} 1 \mathrm{c}$ & 55859. & 55760. & 2.2 \\
\hline 2008227 & $1 \mathrm{Oc} 2 \mathrm{P}$ & 0810 & 0625 . & 6.2 \\
\hline 200838 & $3 \mathrm{Ec} 5 \mathrm{c}$ & 4847. & 441 & 3.9 \\
\hline 200838 & 3 Oc $5 c$ & 4735. & 4247 . & 3.9 \\
\hline 200838 & $5 \mathrm{Ec} 1 \mathrm{c}$ & 23635 . & 23640 & 3.9 \\
\hline 200838 & $5 \mathrm{Oc} 1 \mathrm{c}$ & 23616. & 23622 & 3.9 \\
\hline 2008315 & $1 \mathrm{Ec} 5 \mathrm{c}$ & 62940 & 62916. & 3.9 \\
\hline
\end{tabular}


Table 27. Mutual events of the 2006-2008 period: eventual events predicted with LA06 and GUST86 (9/10).

\begin{tabular}{|c|c|c|c|c|}
\hline $\begin{array}{l}\text { Date (TT) } \\
\text { of maximum } \\
\text { year mth day } \\
\text { Cols. }\left(\begin{array}{lll}1 & 2 & 3\end{array}\right)\end{array}$ & $(4567)$ & $\begin{array}{l}\text { Maximum } \\
\text { LA06 } \\
\text { h m s } \\
(8910)\end{array}$ & $\begin{array}{l}\text { Maximum } \\
\text { GUST86 } \\
\mathrm{h} \mathrm{m} \mathrm{s} \\
\left(\begin{array}{lll}11 & 12 & 13\end{array}\right)\end{array}$ & $\begin{array}{l}\text { (UR) } \\
\text { (14) }\end{array}$ \\
\hline 2008315 & $5 \mathrm{Oc} 4 \mathrm{P}$ & 142434 & 142921 & 3.9 \\
\hline 2008419 & $1 \mathrm{Oc} 5 \mathrm{c}$ & 122813 . & 12263 & 3.5 \\
\hline 2008423 & $2 \mathrm{Oc} 5 \mathrm{c}$ & 141610 . & 142410 . & 1.0 \\
\hline 2008512 & $1 \mathrm{Ec} 5 \mathrm{c}$ & 53848 & 53834 . & 3.9 \\
\hline 2008518 & $5 \mathrm{Oc} 1 \mathrm{c}$ & 12527. & 1243 & 3.6 \\
\hline 2008616 & $1 \mathrm{Ec} 5 \mathrm{c}$ & 12521. & 12410 & 3.8 \\
\hline 2008714 & $5 \mathrm{Ec} 1 \mathrm{c}$ & 222651 . & 222431 . & 3.4 \\
\hline 2008813 & $1 \mathrm{Ec} 5 \mathrm{c}$ & 112151. & 11215 & 3.9 \\
\hline 2008910 & $5 \mathrm{Ec} 1 \mathrm{c}$ & 222859 . & 222641 . & 2.9 \\
\hline 2008910 & $5 \mathrm{Oc} 1 \mathrm{c}$ & 223113 . & 222859 . & 2.9 \\
\hline 20081019 & 3 Oc $5 c$ & 21946 & 211740 & 1.7 \\
\hline 20081022 & $2 \operatorname{Ec} 5 \mathrm{c}$ & 215453. & 22252 & 0.7 \\
\hline 20081023 & 2 Oc $5 c$ & 3728. & 3457. & 3.8 \\
\hline 20081029 & $1 \mathrm{Oc} 2 \mathrm{c}$ & 51029. & 52035. & 1.9 \\
\hline 2008118 & $5 \mathrm{Oc} 1 \mathrm{c}$ & 102716 . & 10271. & 4.0 \\
\hline 20081114 & $1 \mathrm{Oc} 5 \mathrm{c}$ & 33137. & 33034. & 3.9 \\
\hline 2008127 & $1 \mathrm{Oc} 5 \mathrm{c}$ & 10107. & 10946 . & 4.0 \\
\hline 20081213 & $5 \mathrm{Ec} 1 \mathrm{c}$ & 162526 & 162337 . & 3.3 \\
\hline 20081219 & $2 \mathrm{Oc} 5 \mathrm{c}$ & 12318 & 122712 . & 3.7 \\
\hline 20081225 & $1 \mathrm{Oc} 2 \mathrm{c}$ & 213729 . & 214524 . & 1.2 \\
\hline 200912 & 5 Oc $3 c$ & 84636. & 85525 . & 2.1 \\
\hline 200929 & $5 \mathrm{Oc} 1 \mathrm{c}$ & 301. & 2584 & 3.6 \\
\hline 2009217 & $5 \mathrm{Oc} 2 \mathrm{c}$ & 17369. & 17467. & 1.8 \\
\hline 2009222 & 5 Oc $2 \mathrm{c}$ & 5226 & 5322. & 1.6 \\
\hline 200948 & $5 \mathrm{Ec} 1 \mathrm{c}$ & 32054 . & 31538 . & 2.9 \\
\hline 200948 & $5 \mathrm{Oc} 1 \mathrm{c}$ & 5124. & 52553 . & 1.6 \\
\hline 200957 & 1 Ec $5 c$ & 32052 . & 32119. & 2.6 \\
\hline 200957 & $1 \mathrm{Oc} 5 \mathrm{c}$ & 4549. & 41137. & 2.1 \\
\hline
\end{tabular}

Table 28. Mutual events of the 2006-2008 period: eventual events predicted with LA06 and GUST86 (10/10).

\begin{tabular}{lllll}
\hline \hline $\begin{array}{l}\text { Date (TT) } \\
\text { of maximum } \\
\text { year mth day }\end{array}$ & Event & $\begin{array}{l}\text { Maximum } \\
\text { LA06 } \\
\text { h m s }\end{array}$ & $\begin{array}{l}\text { Maximum } \\
\text { GUST86 } \\
\text { h m s }\end{array}$ & $\begin{array}{l}\text { Dist. } \\
(\text { (UR) }\end{array}$ \\
\hline 2009711 2 10 & (4 5 6 7) & (8 9 10) & 5 12 13) & $(14)$ \\
2009113 & 5 Ec 1 c & 17730. & 171727. & 1.3 \\
2009113 & 5 Oc 1 c & 7840. & 10550. & 0.8 \\
2009122 & 1 Oc 5 c & 71210. & 71122. & 3.3 \\
201024 & 5 Oc 1 c & 221927. & 222811. & 1.5 \\
201035 & 1 Ec 5 c & 204210. & 205026. & 0.7 \\
201035 & 1 Oc 5 c & 204447. & 205314. & 0.7 \\
201043 & 5 Ec 1 c & 191812. & 192618. & 0.4 \\
201052 & 1 Ec 5 P & 175029. & 175856. & 0.3 \\
2010531 & 5 Ec 1 c & 162027. & 162914. & 0.8 \\
2010629 & 1 Ec 5 c & 144243. & 14531. & 1.2 \\
20101127 & 1 Oc 5 c & 224449. & 225331. & 0.1 \\
20101226 & 5 Oc 1 c & 212434. & 212935. & 0.3 \\
2011124 & 1 Oc 5 c & 19585. & 20818. & 0.9 \\
\hline
\end{tabular}

